Running Head: STATUS COMPETITION MODEL OF CULTURE

The Status Competition Model of Cultural Production

\author{
Bo M. Winegard \\ Florida State University \\ Winegard@psy.fsu.edu
}

Ben M. Winegard

Carroll College

bwinegard@carroll.edu

David C. Geary

University of Missouri

GearyD@Missouri.edu

**THIS PAPER IS UNDER REVIEW. Please do not use any portion without authors' permission.

This paper may be cited as:

Winegard, B. M., Winegard, B. M., \& Geary, D. C. (2018). The status competition model of cultural production. PsyArXiv.

Corresponding author: Bo Winegard; winegard@psy.fsu.edu 


\begin{abstract}
Humans create many apparently functionless artifacts such as paintings, novels, poems, films, and decorative blankets. From an evolutionary perspective, such creations appear somewhat puzzling. Why create artifacts that do not appear to contribute to survival? One recent explanation, the cultural courtship model, argued that such creations are used to signal genetic health to the other sex. In this way, cultural creators are potentially rewarded with higher quality mates. We propose an alternative (but not completely contradictory) model, the status competition model of cultural production, which argues that cultural displays often, but not exclusively, signal the possession of important cultural competencies to others in a coalition. Cultural creators are recompensed with prestige, which they can use to secure mates or invest in their kin and lineage. We examine evidence for and against these models, and conclude that the status competition model can better explain cultural production than current theory.
\end{abstract}

Keywords: sexual selection, status, evolutionary psychology 


\section{The Status Competition Model of Cultural Production}

After years of arduous study and labor, Immanuel Kant, then in his upper 50's, published his magnum opus, the Critique of Pure Reason. Few people could understand his abstruse book (Kuehn, 2001). More mysterious perhaps than Kant's genius and indefatigable effort is a simple question: why would evolution craft a creature who would devote an inordinate amount of time to writing a recondite book about human knowledge (epistemology)? Darwin's (1859/1958) theory of natural selection suggests that such effort should not be dedicated to the production of a book that does not improve one's ability to survive. To our knowledge, developing an expertise in epistemology does not allow one better to navigate the environment, avoid predators, or discover patches of valuable resources. One currently popular answer, the cultural courtship model $(\mathrm{CCM})^{1}$, argues that cultural productions like Kant's book are designed to enthrall the other sex - that they function like the brilliant plumage of a peacock to capture the attention and tap into the aesthetic preferences of potential mates (Miller, 1999; 2000).

In this article, we argue that the cultural courtship model, although a marked improvement over the often vague functionalist theories propounded by some cultural anthropologists and sociologists, explains only a special subset of cultural productions. We propose an alternative model, the social competition model (SCM) of cultural production, which contends that men and women produce cultural artifacts and displays chiefly to obtain status and prestige from peers and high status others (see also Irons, 1979, and Price \& Van Vugt, 2014, for similar analyses). Prestige and status, once achieved, can be traded for a variety of resources, including, but not limited to, other mates (Perusse, 1993). We argue that the SCM allows a more complete understanding of cultural production and the subsequent mating decisions that such displays affect than current theory affords. 
First, we will describe the cultural courtship model (CCM) and the status competition model (SCM) of cultural production (see table 1). After this, we will judge both models for evolutionary plausibility, using the latest theoretical developments in human evolutionary research. Then we will assess how well each model explains available data.

[INSERT TABLE 1 ABOUT HERE]

\section{What is Culture?}

Although many researchers no longer believe that culture is a uniquely human phenomenon (Lycett, Collard, \& McGrew, 2009), human culture is more flexible and sophisticated than that of any animal. Researchers have yet to document a Chimpanzee penning a love poem, crafting a blueprint, forging iron, or contemplating history. In fact, some scholars have suggested that humans are the "cultural animal" (Baumeister, 2005). Just as dolphins are adapted to their aquatic environment, so too humans are adapted to their cultural environment. And culture has allowed a relatively small and unimpressive ape-homo sapiens - to expand across the globe. But what exactly is meant by this widely used word "culture"? Unfortunately, there are almost as many definitions of culture as there are books on the subject. Obviously, we cannot do justice to this complicated concept nor to the often protracted debates that it inspires (e.g., Baumeister, 2005; Hofstede, 2003). Instead, we will offer a brief but usable definition and a few important distinctions among different cultural artifacts and displays. Culture is a created and transmitted system of values, ideas, and artifacts that affect or shape human behavior (Baumeister, 2005; Kroeber \& Parsons, 1958). This is a rather broad class of phenomena, including everything from a Michelangelo sculpture to a Columbo DVD to a bag of Doritos.

A useful distinction can be made between functional cultural artifacts and displays and ornamental artifacts and displays (Dissanayake, 1990; see also, Davies, 2006). This distinction, 
of course, is more a matter of degree than kind (see figures 1 and 2). Functional cultural artifacts and displays are relatively more utilitarian than ornamental displays. They have an immediate purpose. They solve some problem or fulfill some need. A plastic bag, for example, is a functional artifact. It has a clear purpose: hold grocery items. Ornamental displays, on the other hand, are relatively more decorative (aesthetic) than functional displays. They do not necessarily have a utilitarian purpose; they serve to please or delight others. A Beethoven quartet, for example, is an ornamental display (or artifact if preserved on album, cd, or iPhone). It pleases (or perplexes) those who listen. Generally speaking, ornamental displays and artifacts are associated with what scholars would call art, both high and low. An episode of Columbo, for example, is an ornamental artifact even if many advanced art critics would denigrate it. Obviously, most cultural artifacts and displays combine elements of both. A Frank Lloyd Wright house, for example, is both functional and ornamental. It provides shelter, but it is also carefully designed to please the senses.

The category of ornamental artifacts and displays can be further divided into adornments and enhancements (adorners and enhancers) (see figure 1). Enhancements are cultural products or displays that are used to enhance one's preexisting traits. Makeup, for example, is a cultural product that is designed to enhance one's physical appearance. Breast implants are another. Adornments are cultural products or displays that are not enhancements. This category includes prestige goods such as aged bourbon, expensive watches, signed James Joyce's novels; but it also includes "middle-brow" goods such as fine lagers, Timex watches, John Steinbeck's novels; as well as "low-brow" goods such as cheap beer, "I'm with stupid" t-shirts, and Stephenie Meyer's novels.

[INSERT FIGURE 1 ABOUT HERE] 
Last, any cultural artifact or display can serve as an identifier. Identifiers are cultural products or displays that are used to signal one's allegiance to a specific group. For example, a National Public Radio mug is both a functional artifact and an ornamental adornment that is an identifier. It identifies one's allegiance to liberal values and pursuits (Carney, Jost, Gosling, \& Potter, 2008; Miller, 2010). We will not focus on identifiers in this article, but it is worth considering that many artifacts are purchased and created simply to signify allegiance to one coalition or another.

Again, it is important to note that these distinctions are neither absolute nor exclusive; a single artifact can simultaneously function in multiple ways. A Beethoven album, for example, might signal one's adherence to a classical music association while also signaling one's leisure and exquisite taste. It can, in other words, function as a prestige good and as an identifier. (Many prestige goods are identifiers of one kind or another.)

\section{[INSERT FIGURE 2 ABOUT HERE]}

\section{Theories of Cultural Production}

At first blush, the answer to the question, "why do humans build culture?" is astonishingly obvious: because it helps them survive. But many cultural products, as discussed above, do not actually help humans survive. Kant's Critique of Pure Reason offers little advice about surviving in a hostile world. Furthermore, the pronoun "them" in the sentence "it helps them survive" is a problem. Evolutionary theorists no longer believe that evolution operates for the good of the species (Williams, 1966). Any theory of cultural production that hopes to survive in a Darwinian world must explain how the production of culture provides benefits for the individuals who invest time and energy in such products. It also must explain why people would 
create and consume cultural products that appear unrelated to survival such as NPR mugs and symphonies.

Below, we outline two possible proposals that fulfill these criteria. The first, the cultural courtship model (CCM), was an intriguing suggestion forwarded by Geoffrey Miller. The second, the status competition model, is our proposal.

\section{Cultural Courtship Model}

The cultural courtship model (CCM) argues that human culture is not a system of functional responses to basic survival needs as Malinowski and others argued (Malinowski, 1944), rather it is a series of displays aimed at alluring potential mates: "...human culture is mainly a set of adaptations for courtship" (Miller, 1999, p. 72). Just as swallows sing, peacock's strut, and spiders dance, so humans write poetry, play guitars, erect buildings, and propagate ideologies. According to Miller (2000), cultural displays are well suited to seduce the other sex (largely but not exclusively men displaying for women), because they are designed to designate underlying biological fitness. Top-notch cultural displays require exquisite skill to produce, and many cultural displays are organized and ritualized so that observers can easily distinguish between high quality and low quality productions. The skills required to produce masterful cultural products, according to this perspective, are genetically heritable and therefore the cultural products are indicators of heritable fitness qualities. These might ultimately reduce to a general "fitness factor," which is an index that predicts a person's overall survival and reproductive success (Miller, 2001). However, the important point, whatever the nature of this putative fitness factor, is that most cultural displays and creations are signals that broadcast the producer's genetic quality—often to potential mates. 
The CCM is completely consistent with a gene-centered view of cultural production. Culture is not something humans do to thrive as a species. It is a courtship activity that (mostly) men do to enhance their appeal to women. The adaptations that gave rise to the proclivity to create cultural displays were selected by the mating decisions of women. Adaptations that facilitated cultural products that pleased women reproduced and thrived (because the underlying genes reproduced). Those that did not, did not. None of this is necessarily conscious.

Michelangelo may have earnestly desired to honor his god with his brilliant paintings and sculptures. But, beneath this divine motivation, according to the CCM, there is a practical evolutionary function. Consider a different example. Take a spider. If you asked a (hypothetical talking) spider why it spins webs, it would probably earnestly answer, "because I love to spin webs, and I want to honor my ancestors who also spun webs." We know that the spider's webspinning behavior has an evolutionary logic of which the spider is entirely ignorant; and so, according to the CCM, we also know that humans' cultural behaviors have an evolutionary logic of which most of humans are entirely ignorant. ${ }^{2}$

\section{The Status Competition Model}

The status competition model (SCM) argues that Miller and Malinowski are both correct: Culture is a system of signals to other humans, and culture is often functional. It is not functional because humans conspired to design a useful niche to increase their reproductive fitness as a species; rather, it is functional because evolution hit upon a brilliant solution to the problem of collective action: a status-exchange system. A status-exchange system is a social system in which organisms exchange status and prestige (having status and prestige allows one to access important resources) for prosocial behaviors such as leading a tribe in battle that require immediate sacrifice. Applied to cultural products and displays, this means that humans defer 
(give status) to people who create useful or functional cultural artifacts or who signal (culturally) the possession of traits that benefit the individuals in a coalition (Anderson \& Kilduff, 2009; Henrich \& Gil-White, 2001; Willer, 2009). This freely-conferred deference_-also called "prestige" or "status" - is a form of mutualism (reciprocal exchange of benefits), because the person who collects status is given preferential access to valuable resources, and those who defer to him or her are better able to compete against other coalitions (Winegard, Winegard, \& Geary, 2014).

The CCM was correct that many cultural displays are signals. However, according to the SCM, cultural displays are signals that are aimed at other coalitional members (or potential coalitional members) and that communicate the possession of culturally relevant competencies. Kant's Critique of Pure Reason, for example, signaled the possession of a keen intelligence and an expansive erudition. These competencies may change from one culture to another and across time, thus explaining why different cultures at different times value different types of cultural displays. For example, in a technologically based culture, mathematical ability might be valued because of its economic importance. However, in an agricultural society, expansive knowledge of plants might be valued (Davis \& Moore, 1945). This motivation to signal the possession of cultural competencies, and not the motivation to woo the other sex, is the primary reason for human's cultural displays. The SCM does not claim that this is the only reason men and women display cultural artifacts; and, in fact, it is reasonable to posit that some cultural displays are targeted at the other sex. Furthermore, it is quite likely that the status that is achieved through cultural displays is often used to captivate the other sex (see figure 3). However, such status might be used to invest resources in one's kin, or even to enhance the prestige of one's lineage (Geary \& Flinn, 2001). 
The SCM also appears consistent with a gene-centered view of cultural production. Culture is (1) an activity that enhances the social appeal of men and women to other men and women and (2) a series of practical solutions to pressing problems. Adaptations to create culture thrived because they enhanced their owner's prestige in a coalition. This prestige allowed access to coveted resources, often including mates. As with the CCM, the SCM contends that cultural creators are often oblivious to the ultimate cause of their creative passions; they simply want to excel vis-à-vis others and use whatever talents they have to create products and artifacts that confer prestige within their group. To take an example from the Renaissance, Savonarola, a passionate preacher of the late 1400's, probably earnestly believed that his teachings were inspired by an inveterate pursuit of justice and divinity. However, according to the SCM, whatever the metaphysical truth or falsity of his sermons, his desire to spread his vision of holiness existed because his (hominin) ancestors who possessed such desires reproduced more than those who didn't.

\section{Summing Up the Theories}

The CCM and SCM are similar in many ways. Both theories contend that a good portion of ornamental culture is produced or displayed to signal the possession of underlying traits to an audience. However, the theories propose that such items are created and displayed for different audiences. The CCM asserts that most ornamental (adornments) displays are created by men and are aimed at women to impress, allure, and perhaps beguile them (Kanazawa, 2000). It should be noted, however, that Miller and others have argued that a kind of cultural courtship model is congruent with a mutual mate choice model of evolution (Hooper \& Miller, 2008; StewartWilliams \& Thomas, 2013). A mutual mate choice model is less clear about which sex should produce more cultural displays. Cruder versions of the CCM tell tales of male cultural 
production and female cultural assessment. These have been repudiated by Miller (2013), although he does note that men might still invest relatively more time and effort in displays to broader audiences. The important point, here, is that the CCM argues that ornamental cultural products and displays are genetic fitness indicators signaled primarily to the other sex ${ }^{3}$.

The SCM is consistent with the proposal that most ornamental displays have been created by men; however, it contends that many of these displays have been aimed at other men not women. Throughout history men, not women, have most often possessed power in society (Goldberg, 1999). Because the SCM argues that ornamental displays are often used to signal the possession of cultural competencies to obtain status from individuals in a coalition (tribe, community, institutions, society), it argues that such displays will often target high status and high powered people. For most of human history, this would have been men. A man, say Savonarola, who desired status in Renaissance Italy would have targeted the powerful men (or the masses, who could confer power; that is, if one convinced enough of the masses of one's righteousness, one could achieve power) who could bestow such status. If he had appealed only to women, he would not have achieved the status he desired because women did not have the power to confer it. (Of course, as we will discuss later, there are alternative strategies. Some men might have targeted--and may still target--women with their ornamental displays.)

The SCM contends that these cultural products and displays are generally not genetic fitness indicators; rather, they are immediate indicators of the possession of culturally valued competencies. Audiences are dazzled or disappointed by displays not because they suggest a low mutation load or general fitness, but because they suggest important skills and talents that might benefit other individuals in a coalition. There is likely a correlation between one's skills and talents and one's underlying genetic quality. A person who has fewer genetic mutations and 
therefore a more "precisely" designed brain would probably have more mental horsepower than others who didn't. Ceteris paribus, a person with a more powerful mind would have the capacity to develop more or better cultural competencies than a person with a less powerful mind. But, what is important according to the SCM is the current possession of the competencies, not the underlying brain, body, or genes.

If the SCM's contention about the intended target of ornamental culture is true, the features and content of cultural (ornamental adornments) artifacts and displays should, on average, appeal to men more than to women. That is, on average, men should enjoy such artifacts more than women. This prediction directly contradicts the CCM's prediction that ornamental artifacts and displays should appeal more to women than to men. The evidence for and against this prediction, therefore, will be an important part of our analysis when we examine the evidence for and against the SCM. The SCM does not argue that men are necessarily intrinsically motivated to create cultural displays for other men; rather, it argues that men are intrinsically motivated to create cultural displays for other high status and powerful members of one's symbolic coalition (or a coalition one would like to join) (Berreby, 2005). If women controlled society and its institutions, men would probably produce cultural products to impress women. However, because men have played dominant roles in human coalitions for many thousands of years, if not millions, men may have evolved intrinsic desires to produce artifacts and displays that are more rewarding and enjoyable to other men than to women. This, of course, is an empirical question.

The SCM contends that roughly the same explanation that works for ornamental cultural artifacts and displays also works for functional cultural products. Consider an arrowhead. If someone makes a particularly effective arrowhead — one that is, say, sharper and more 
aerodynamic than other arrowheads_-, then other people would benefit from obtaining it or learning how to make it. The creator, however, would not simply give away the arrowhead or show others how to make it. He or she would want something in return. According to the SCM, this something is status. People who create cultural artifacts that solve pressing problems or fulfill important needs are rewarded with freely conferred status; people willingly defer to them (Anderson \& Kilduff, 2009). This benefits both the creator and those who defer to him or her. It benefits the creator because it enhances his or her prestige, which allows him or her preferential access to important resources; and it benefits those who defer because it allows them access to the cultural artifact (or to instructions about how to make it). Bill Gates is one example of a great inventor who was handsomely rewarded for producing functional cultural products that enhanced the lives of many people.

It is not entirely clear what the CCM says about functional cultural products. Instead, the CCM attempts only to explain the circumscribed sphere of ornamental cultural artifacts and displays. Both theories are relatively silent about the use of enhancements, or cultural artifacts or displays that amplify the quality of a person's phenotype. The SCM, however, is congruent with a view of human evolution that emphasizes male mate choice (Puts, 2010). If this picture of human evolution is correct, then a straightforward prediction of the SCM is that women should use more enhancers than men. However, this prediction is also congruent with the CCM, which emphasizes some degree of mutual mate choice. We will touch upon functional cultural items and ornamental enhancers only briefly in this text, because neither domain provides an especially useful test of the theories. Instead, we will focus chiefly on ornamental adornments.

The real arbiter of any theory is the evidence. Because both theories are strongly influenced by contemporary theories of evolution, we begin with an overview of the evolutionary 
evidence. Much of this is, perforce, theoretical. The proverbial caution that behavior does not fossilize is applicable. But that does not mean we are completely in the dark about our past. The CCM and the SCM rely upon different conceptions of human evolution. These can be assessed for plausibility, using the best evidence available. Therefore, we turn to human evolution below. [INSERT FIGURE 3 ABOUT HERE]

\section{The Evolution of a Cultural Animal}

Although there is not one evolutionary theory that definitely declares a theory of cultural production a winner over another, we can assess evolutionary scenarios of the expansion of the brain and increasing cultural capacities for how consistent they are with current theories of cultural production (Geary, 2005). First, we will cover the evolutionary scenario presented by Miller (2000) in his book, The Mating Mind. This scenario, not surprisingly, is well fitted to the cultural courtship model. After, we will challenge this scenario and present an alternative scenario that combines components of an ecological dominance and social competition model with other models (Alexander, 1974; Pinker, 2010) that argue that the human mind emerged from the crucible of natural selection as humans opened and began to inhabit a novel cognitive niche (Deacon, 1997). We then assess the assumption that humans engaged in free or relatively free mating and marriage decisions. Modern scholarship, we believe, severely challenges the notion of free mate choice, and therefore casts doubt on an important element of the cultural courtship model.

\section{The Basic Background}

There are several consistent and progressive, although not linear, trends in hominin evolution. Two of the most important, at least for the purposes of this paper, are the evolution of increasing brain size, as indicated by cranial capacity, and the development of complicated 
cultural artifacts such as tools, weapons, and art (Aiello \& Wheeler, 1995; Klein, 2009). From 3.5 mya to the birth of modern humans, there is a dramatic increase in brain size. Whereas Australopithicus species' cranial capacities ranged between 300-560 cc (Asfaw et al., 1999; Falk, et al., 2000), early Pleistocene Homo Erectus cranial capacities ranged between 600-1057 cc (Lee \& Wolpoff, 2003). Modern human cranial capacities range from roughly 1250 cc to roughly 1500 cc (Rushton \& Ankney, 2009). This period of hominin evolution also evinces a significant increase in technological complexity and cultural activity (Elton, Bishop, \& Wood, 2001; Foley \& Lahr, 2003). The earliest tools and tool kits gradually morphed from the relatively primitive scrapers, choppers, and pounders of the Oldowan (roughly $2.5 \mathrm{mya}$ ) to the more sophisticated hand axes of the Acheulean (roughly 1.7mya). From there, culture artifacts continued to progress, although the general Acheulean industry was used for a remarkable period of time. Roughly 60,000-50,000 years ago, there may have been a "cultural explosion" (Klein, 2009)_although some dispute this contention (McBrearty \& Brooks, 2000). It is certain that a range of novel artifacts shows up in the archaeological record around 60,000-50,000 years ago, including many ornamental artifacts. After this, the archaeological record begins to bloom with more complex artifacts and displays, including gorgeously painted caves in many locations across France and Spain (Klein, 2009).

\section{A Mind for Mating}

According to Miller (2000), the brain is a sexually selected signal sending system:

"Sexual selection made our brains wasteful, if not wasted: it transformed a small, efficient apestyle brain into a huge, energy hungry handicap spewing out luxury behaviors like conversation, music, and art” (p. 134). From this perspective, hominin brain size increased dramatically 
because a larger, more elaborate brain can better signal its owner's fitness than a smaller, less ornate one. Let us unpack this.

Miller contended that the brain evolved to display (signal) its owner's underlying fitness. More precisely, the brain signals its owner's mutation load, or number of deleterious genes that are carried by the owner's genome. Evolution relies on genetic mutations. They are the grist for natural selection's mill, so they might seem a good and necessary thing (Ridley, 1993). But most mutations are either neutral or deleterious--they often hinder not enhance an organism's ability to survive and reproduce. But every genetic lineage inevitably accumulates harmful mutations (Agrawal \& Whitlock, 2012). Sexually reproducing species, such as humans, can somewhat control the mutation loads of their offspring by reproducing with partners who evince low mutation loads. But how does one determine the mutation load of another person? People do not have mutation load displays on their foreheads.

According to Miller, the human brain is a brilliant indicator of one's underlying mutation load because the brain is constructed from information from thousands of genes. With so many genes on display, mutations are bound to show up. Brains that are relatively mutation free are healthy, intelligent brains. Such brains can produce complicated artworks, clever jokes, insightful apercus, and engaging conversation. These features of the human cultural world might appear functional, but according to Miller, "from a biological viewpoint they might signify nothing more than our fitness, to those who might be considering merging their genes with ours" (p. 134). Brain expansion wasn't a functional response to a hostile environment, dangerous predators, or competing humans; it was a wasteful response to choosy sexual partners.

From this perspective, many of the increasingly complicated cultural artifacts that appear in the archaeological record weren't compelled by environmental exigencies; they were 
compelled by the mating decisions of the other sex. Although this argument might seem silly when applied to "obviously" functional tools such as hand axes, other scholars have suggested that the symmetrical design of such axes made them excellent sexually selected signals (Kohn \& Mithen, 1999). More obviously ornamental displays seem to fit the CCM's contention that many cultural displays and artifacts are signals. Dazzling cave paintings, sumptuous stone sculptures, and intricate bead necklaces seem more of a signal than a functional response to an environmental challenge. But what exactly do they signal?

\section{A Brain for Battle}

A number of researchers have argued that hominins' increasing brain size was spurred by social competition (Alexander, 1990; Geary, 2005; Humphrey, 1976; Flinn, Geary, \& Ward, 2005). According to this argument, as humans began to achieve ecological dominance — began to master local resources and to thwart potential predators - they became each other's own "hostile forces of nature" (Alexander, 1990, p. 4). This is also congruent with Pinker's (2010) recent contention, following Tooby and Devore (1987), that humans evolved to exploit a cognitive ecosystem, and that this specialization led to the evolution of language, recursive cognition, causal reasoning - in other words, led to the traits that make culture possible. We believe that a social competition model of human evolution is both plausible and parsimonious. We unravel this below.

According to the social competition/cognitive niche hypothesis, many uniquely human traits evolved concomitantly as each trait buttressed the other traits. In this sense, the suite of uniquely human traits (language, cooperation, cultural production) was a self-reinforcing manifold. Each change in one trait allowed and supported changes in other traits. The catalyzing variable(s) of this process is debatable, but some researchers have speculated that pair bonding 
was an important preliminary step (Chapais, 2008). Pair bonding increased the number of discernible kin (offspring now recognized their fathers and their father's relatives), which supported the development of broader coalitions consisting of multiple family units (Chapais, 2013). This increase in cooperation and interdependence allowed for sex-role specialization and more intensive parenting, which, in turn, allowed for the development of bigger brains and longer periods of adolescence (Smith \& Tompkins, 1995). Extended adolescence and bigger brains allowed for increases in social learning and placed a premium on effectively transmitting social information.

As hominin coalitions expanded, the importance of coalitional members also expanded. Furthermore, as coalitions grew, the genetic relatedness of the individuals in the coalitions diminished. Reputation became increasingly important, perhaps leading to costly signals of prosociality (Jaeggi, Burkart, \& Van Schaik, 2010; Nesse, 2007; Norenzayan \& Sharriff, 2008; Winegard, Reynolds, Baumeister, Winegard, \& Maner, 2014). The ability to discriminate between cheaters and committed coalitional members almost certainly exerted more pressures on the brain (Pinker, 2010). Cooperation is potentially costly and perilous because individuals may accumulate benefits without returning favors (Trivers, 1971). Humans appear to have solved this problem by developing a "status-exchange" system (Anderson \& Kennedy, 2012; Henrich \& Gil-White, 2001). As previously noted (see the section on the SCM) a status-exchange system solves the puzzle of sociality by positing that individuals who perform a behavior that benefits a group receive payment in the currency of deference and prestige (Anderson \& Kilduff, 2009; von Ruden, Gurven, \& Kaplan, 2011). In other words, a human ancestor who created a new technology that benefited his or her group would have been repaid by the esteem and deference of his or her peers; therefore, his or her efforts would not be unpaid, and his or her cultural 
creation could be used by his or her group to battle more effectively against other groups. This allowed cultural production to flourish.

Although many of the products of this incipient culture were used for gathering or extracting nutrition from food stuffs (Marlowe, 2005), the presence of competing coalitions quickly led to a proliferation of weapons. In fact, some theorists have proposed that the development of throwing weapons played a significant role in the further evolution of modern humans (Bingham, 1999). Mortal combat between coalitions intensified the importance of cooperation, cognitive capacities, and cultural products (weapons and tactics). Brain expansion increased the cognitive skills of human ancestors, making them more culturally deft. Cultural products gradually became less functional. Coalitions needed to assess members, to determine their skills, talents, and potentials. Men and women began creating ornamental cultural artifacts and displays, and these signaled the possession of traits and talents that could benefit others.

\section{Sexual and Social Selection: How Free was Mate Choice?}

Since sexual selection theory was rehabilitated in the 1970s, researchers, following Darwin's observation that "The exertion of some choice on the part of the female seems almost as general a law as the eagerness of the male" (Darwin, 1871, p. 273; Miller, 2000), have emphasized the importance of female choice. Men, it has been argued, compete through displays of fitness to better their chances of being picked by freely choosing women. This framework forms a crude version of the CCM. Men display cultural productions, which advertise their fitness, to women to impress and allure them. A more sophisticated version of the CCM, one more consistent with Miller's $(1999 ; 2000)$ original proposal, argued that both men and women exercised free mate choice: "Throughout this book I have proposed the importance of mutual mate choice..." (Miller, 2000, p. 376, emphasis added). In a mutual mate choice scenario, both 
men and women compete to secure the affections of the other sex. However, the contention that women (or men) had free choice during most of hominin evolution has been challenged by recent research. Furthermore, both men and women may have competed for resources other than sexual partners. These two facts cast doubt on the CCM, but are consistent with the SCM, as we explain below.

Apostolou (2007; 2010) has argued that the emphasis on free mate choice in human evolution has caused researchers to ignore an important filter of (especially female) mate choice: parents and other kin. In many human societies, a woman's parents and kin exert a strong influence over her mate choices. Because marriage is an important way of coalescing disparate families into a competitive social unit with mutual obligations, parents and brothers are crucially affected by the mating decisions of a daughter and/or sister. If, for example, a daughter decided to marry an impecunious man with a disreputable family, her father would not have obtained a potential alliance with a stronger, more prestigious family. Arranged marriage has probably characterized the human species at least since the modern dispersal out of Africa (Walker, Hill, Flinn, \& Ellsworth, 2011). And it was prominent in many pre-modern civilizations, including Classical Greek, Imperial Roman, Medieval Arab, and pre-Victorian English (Apostolou, 2010).

Other researchers have argued that because men could simply physically overpower and coerce women, the mating decisions of women were much less important than some prominent evolutionary psychologists have argued. Puts (2010) noted that although humans are not so obviously sexually dimorphic as gorillas or other "harem" animals, men are substantially stronger than women. In fact, the effect size for the difference between men and women on measures of total and upper body muscle mass is actually comparable to the difference between male and female gorillas (Lassek \& Gaulin, 2009). Puts further argued that many traits that men 
possess seem "designed" to intimidate, threaten, or exclude potential male rivals, not to attract women. He concluded that men probably battled each other for control over women, and that the chief driving force of sexual selection on men was not female choice but rather contest competition with other men (see also Geary, 2010).

The notion that men battle each other, sometimes mortally, to obtain or preserve mates is not novel, although Puts (2010) emphasized it while concomitantly deemphasizing female mate choice. Darwin, for example, noted that males competed vigorously against each other for access to females (Darwin, 1871). And such insights have inspired and guided research on sex differences across the animal kingdom. In humans, it has particularly guided research on male aggression. However, such competition and conflict is not necessarily a form of sexual selection. West-Eberhard (1979; 1983), for example, noted that social competition for resources other than mates is common across the animal kingdom and argued that sexual selection is a subset of this broader category of competition. Females in many species battle for access to broader swaths of territory, for more propitious breeding sites, or for other resources and these "may or may not be indirectly related to reproduction" (Rubenstein, 2012, p. 2304). Similarly, humans may compete socially for resources that are not directly related to mating (Nesse, 2009). Men, for example, may compete against each other for access to status and resources because status and resources can be transferred to offspring (Buss, 2008; Cecil, 1895). Many societies are patrilineal, and offspring therefore receive their father's family name, which can provide substantial benefits (Jobling, 2001). For example, the surname "Medici" conferred significant advantages to a child during the Italian Renaissance. Today, the same may be true of the last names "Gates," "Jobs," “Jordan," "Rockefeller," or "Kennedy."

\section{Assessment of Evolutionary Evidence}


All researchers agree that hominin evolution evinces a pattern of increasing brain expansion and cultural complexity, even if they disagree on the details. The CCM is completely consistent with Miller's contention that the human brain expanded because it signaled genetic fitness to members of the other sex. However, it is also consistent, although less clearly, with a social competition theory of human evolution. That is, one does not need to accept the relatively bold theory that the human brain is a sexually selected organ to buy a version of the CCM. For example, it is possible that the human brain was forged by the crucibles of intense social and intrasexual competition, but that the sexes also signaled with cultural displays to entice each other. However, the CCM is not consistent with a view of evolution in which there is limited female mate choice and in which there is intense competition and signaling for resources such as status that are bestowed by all coalitional members, not just members of the other sex. Of course, this latter perspective does not preclude all signaling related to mating; it simply contradicts a strong version of the CCM.

Although we cannot assess these competing evolutionary scenarios as sedulously as we would like, we do believe that current evidence supports a version of the social competition/cognitive niche scenario in which men were the predominant players in aggressive coalitions and in which female mate choice played less of a role in sexual selection than many evolutionary psychologists have hitherto recognized (with exceptions, see Puts, 2010). For example, as predicted by the social competition theory, men exhibit stronger coalitional propensities than women. Men are more tolerant of strangers than are women (Benenson, 2013), and they often interact in larger social networks than women (Geary, 2010). Men are more interested in things than women and are cognitively more systematic (e.g., categorizing objects) than empathetic relative to women (Baron-Cohen, Richler, Bisarya, Gurunathan, \& 
Wheelwright, 2003; Su, Rounds, \& Armstrong, 2009). These cognitive differences are likely the result of an evolutionary history of coalitional combat. Men engaged in more coalitional planning and organizing than women, which required a desire and ability to break apart coalitions systematically, whereas women engaged in more small-scale, dyadic social interactions, which required a desire and ability to read other people's emotions. Men are also more motivated to obtain power and are less likely to endorse egalitarian narratives (Schwartz \& Rubel-Lifschitz, 2009); men, on average, believe that some groups (coalitions) are better than others, and that the winners of coalitional conflicts should reap benefits, which is consistent with an evolutionary history of coalitional clashes and competition (Pratto, Stallworth, \& Sidanius, 1997).

As predicted by a theory of human evolution that emphasizes male contest competition and relatively little free female mate choice, men possess many physical traits that appear optimally designed to impress or intimidate other men rather than to attract women. Puts (2010) argued that beards and low-pitched voices, for example, are used to signal dominance to other men, not to allure women. Dixson and Vasey (2012) confirmed this for beards, showing that they increased perceptions of men's age, social status, and aggressiveness, but not attractiveness. Hodges-Simeon, Gaulin, and Puts (2011) supported the argument that low-pitched voices signal dominance to other men. They found that the mean fundamental frequency of a man's voice used when communicating with an ostensible competitor predicted the number of past-year sex partners; however, the mean fundamental frequency of a man's voice used when communicating with an ostensible woman did not predict past-year partners. Other research has shown that men's muscularity follows this pattern. Frederick and Haselton (2007), for example, showed that women found muscularity attractive only to a certain point ("built"); after that point, their ratings 
declined. However, men found increasing muscularity more dominant all the way through the assessment (to "brawny"). This pattern holds for faces as well. Windhager, Schaefer, and Fink (2011) showed that the faces of physically strong men were more similar to faces that women perceived as dominant than to those they perceived as highly attractive.

Compare this with women, who appear to possess many physical characteristics designed to entice men and few designed to physically threaten or intimidate rivals. For example, human breasts are larger than is necessary to produce milk for offspring, and they appear to serve as ornaments that appeal to men (Cant, 1981; Marlowe, 1998). Breasts, in fact, are often cumbersome, hindering rather than helping in possible physical conflict. Women's fat distributions (gynoid) also appear ornamental — perhaps signaling fertility or fecundity to men (Cant, 1981; Jasienska, Ziomkiewicz, Ellison, Lipson, \& Thune, 2004). Women's lips, hair, and skin might also serve similar functions. Of course, men do possess traits that signal health to women. However, the important point is the relative comparison of the manifold of each sex's secondary characteristics. Some of men's traits are clearly designed to intimidate and defeat potential rivals. Almost none of women's traits appear designed for similar purposes. It is worth noting, however, that many of women's psychological competencies such as language fluency are well designed to aggress socially against other women (Geary, 2010).

\section{The Evidence from the Modern World}

Competing hypotheses. The CCM and the SCM make several similar hypotheses (see Similarities and Differences section above; also, see table 1). For example, both models are consistent with the hypothesis that men have (will) produced more ornamental (adornment) displays than women. Although the CCM, as proposed by Miller (2000; 2013), relies upon a model of mutual mate choice, it does suggest that men might invest more time and energy into 
public cultural displays than women. The SCM contends that men have produced more cultural artifacts (ornamental adornments) than women. It also predicts that they will for at least the immediate future because men remain the primary players in coalitional conflicts and political clashes. It is reasonable to posit that men have different psychological propensities and desires than women and that these will cause the current pattern of cultural construction to continue despite an increasingly open and sex equal society (Baumeister, 2010; Geary, 2010; see also section Assessment of Evidence). However, this is not a necessary posit of the SCM.

Both are also consistent with the hypothesis that women will consume and use more ornamental enhancements than men. As noted in the previous section, the SCM accepts a theory of human evolution that emphasizes male contest competition. The male contest competition framework actively predicts that women should use more enhancers than men; the CCM, on the other hand, does not appear to make a prediction about the use of enhancers. The CCM is relatively quiet about functional cultural artifacts. The SCM suggests that functional artifacts should follow roughly the same pattern as ornamental (adornments) artifacts. These last two hypotheses, however, would require a longer article than we are prepared to force upon our readers.

Where do the models most clearly differ? The CCM and the SCM propose different audiences for the cultural products and displays that men and women create. Specifically, the CCM hypothesizes that the audience for cultural displays (and more specifically, for ornamental adornments) will often be the other sex from the displayer. The SCM, on the other hand, hypothesizes that the audience for cultural displays will be whoever can confer status and prestige in a particular society (with caveats that were addressed in the section on the SCM). It follows that the CCM predicts that cultural displays should be designed to allure the other sex, 
whereas the SCM predicts that cultural displays should be designed chiefly to impress other $\operatorname{men}^{4}$.

Below, we will examine data that support and possibly contradict these hypotheses and also other data that might reflect on the theories. Because there is a paucity of data on men's signaling behaviors to other men, we will use some data that show that men are conscious and protective of their reputations among other men. These data do not contradict the CCM, but they do provide support for the SCM.

Data that support the CCM. As noted, the CCM predicts that men will probably invest more time and energy creating and displaying cultural artifacts than women (ornamental adornments). Furthermore, it predicts that "cultural production should increase rapidly after puberty, peak at young adulthood when sexual competition is greatest, and gradually decline over adult life as parenting eclipses courtship" (Miller, 1999, p. 81). Miller found support for both of these predictions. He examined jazz albums, novels, and paintings and found that each was overwhelmingly produced by young or middle-aged adult men. Kanazawa (2000) also found support for this pattern in the field of science. Building from Miller's contention that the decline in motivation for producing cultural artifacts is due to a shift in effort from courtship to parenting, Kanazawa further argued that marriage and reproduction should attenuate a man's desire and motivation to produce cultural displays. This hypothesis was also confirmed in Kanazawa's sample of scientists. Farrelly and Nettle (2007) found a similar performance decline for elite married male tennis players.

A more indirect prediction of the CCM is that men who are temporarily motivated to mate (i.e., who have been primed with mating motives) should display more cultural artifacts, especially conspicuous cultural artifacts. They should also display more vigorously, perhaps 
dangerously, if in front of female observers. These tendencies may also be moderated by men's preferences for short versus long-term mating strategies, with men who are oriented toward short-term mating using cultural displays more actively to advertise their underlying fitness than men who are orientated toward long-term mating.

Researchers have found support for the prediction that mating motives influence men's display patterns and behaviors. For example, Griskevicius, Cialdini, and Kenrick (2006), found that men who were primed with mating motives increased their creativity when writing short stories. In these studies, men's creativity increased when primed with either short-term or longterm mating. In a 2007 study, Griskevicius et al. found that men primed with mating motives indicated that they would spend more money on conspicuous items than men in a control condition. The study also found that men primed with mating motives desired to help others in "heroic" (possibly dangerous) ways more than men in a control condition. Sundie et al. (2011) found similar effects and also that the results were moderated by scores on the sexual orientation inventory (SOI), a measure of one's orientation toward short-term or long-term mating. Specifically, men who scored one standard deviation higher than the mean on the SOI (thus, engaged in a relatively short-term strategy), indicated a desire to spend more money on conspicuous luxury items than men in the control condition. (It is important to note that some of these studies might not replicate; and given widespread skepticism about the efficacy of priming methods, we believe that caution is in order when interpreting the results.) Ronay and Von Hippel (2010) found results congruent with this general pattern. In their study, a male or a female experimenter recruited skateboarders in a park to perform one "easy" and one "hard" trick. In the female experimenter condition, the skateboarders were less likely to abort a dangerous trick, leading to more crashes, but also to more successful tricks. Bruises, apparently, were a small 
price to pay to impress an attractive woman. Other studies, using different methodologies, have found similar results: men display, often in a costly manner, to impress women (e.g., Baker \& Maner, 2008; Frankenhuis, Dotsch, Karremans, \& Wigboldus, 2010; Saad \& Vongas, 2009; Van Vugt \& Iredale, 2012).

Contradict the SCM? The SCM argues that many of men's and women's (ornamental) cultural productions and displays are aimed at other coalitional members who can bestow status (often men), not potential mates. It does not argue that men are the exclusive target of cultural displays, nor that displayers are impervious to the presence of women. With this in mind, the priming studies from above, although informative, do not provide a test between the two theories, because the men in the mating prime condition were compared to men in a control condition that was not related to social competition. For example, in the Ronay and Von Hippel (2010) study, an attractive female experimenter was pitted against an eighteen-year-old male experimenter - presumably one without significant status. If the experimenter had been a high status man — say Tony Hawk, an especially prestigious skateboarder - the results might have been different. We are not aware of any studies that have pitted high status men (or high status women) against attractive women. Would a high status person provoke competitive and showy displays? Would a social competition prime? (If primes work??) Would these be stronger than a mating prime or an attractive member of the other sex?

Data that broadly support the SCM. Many studies are at least broadly supportive of the SCM. Importantly, many of these do not contradict the CCM; they simply provide support for the SCM. For example, several studies suggest that men engage in riskier behavior when with or observed by other men than when with or observed by other women. Jackson and Gray (1976) found that men were more likely to drive aggressively when their passengers were men than 
when they were women. Similarly, Nuyts and Vessentini (2005) found that male drivers were more likely to wear a seatbelt when women were in the car than when the car was empty. They were least likely to wear a seatbelt when other men were in the car. Wilson and Daly (1985), in an overview of risk-taking and violence, noted that an ideal of "masculinity" and a desire to protect one's reputation often compel men to take risks and to engage in violent, potentially mortal conflicts with other men. Indeed, masculine honor codes are zealously protected by men (Nisbett \& Cohen, 1996; Polk, 1999).

The culture of honor is mainly perpetuated and endorsed by men, who assiduously inspect and judge each other's reputation. In such cultures, male prestige is linked to risk taking behavior and a willingness to defend aggressively resources, allies, women, and reputation (Barnes, Brown, \& Osterman, 2012; Barnes, Brown, \& Tamborski, 2012). Laboratory research is consistent with these arguments. Willer, Rogalin, Conlon, and Wojnowicz (2013) found that when men received bogus feedback that they were "feminine," they expressed more support for war and more desire to purchase an SUV. They also found that men reacted to similar threats with augmented support for and enthusiasm to climb hierarchies. This suggests that men have a deep rooted desire to maintain esteem among other men and that this desire motivates men to gain status and prestige through flaunting competencies and cultural artifacts (e.g., possession of SUV's).

Other research suggests that men and women may flaunt personality qualities such as niceness and moral values such as altruism (sometimes through products) to obtain status from both men and women. For example, Griskevicius, Tybur, and Van den Bergh (2010) found that activating status motives influenced men and women to choose "showy" (conspicuous) green, environmentally friendly products over traditional luxury products more than in a control 
condition (no motives activated). Possibly the green products were a kind of prosocial signal that could elicit approval and deference from others. Along these lines, Hardy and Van Vugt (2006) found that those who contributed more to a group fund than others were recompensed with more status than others. Also, Bereczkei, Birkas, and Kerekes (2007) found that both men and women were more likely to make charity offers in front of others than when isolated and concealed. Presumably, this logic extends to many cultural displays such as blood donor shirts, conspicuous contributions to public projects, environmentally friendly houses, politically active and morally righteous music, et cetera (see, for example, Dastrup, Graff Zivin, Costa, \& Kahn, 2012; Sexton \& Sexton, 2014).

Men also seem to target other men for displays of athletic or physical prowess. Indeed, Lombardo (2012) posited that sports function as a kind of male-lek in which men can assess each other's capacities to engage successfully in intergroup conflict. Several domains of evidence support this contention. Sports are ancient and universal (Guttman, 2007). In all societies, including industrialized societies that encourage female participation in sports, men engage in team sports more than women (Deaner et al., 2012; Deaner \& Smith, 2013). One might argue that this fits the predictions of the CCM, because men play to display their physical fitness and genetic quality to women. However, men attend more sporting events than women; they enjoy and care more about sports than women; and they know more about sports than women, including especially the esotera of statistical analyses that are crucial to assess an athlete's productivity (Guttman, 1986; James, 2001; James \& Ridinger, 2001; Winegard \& Deaner, 2010). WAR (wins above replacement in baseball — how many wins a player contributes to his team above a replacement player) may not sound sexy, but it is the most objective measure of a baseball player's performance and is therefore a good gauge of that player's putative fitness- 
one that men seem enthusiastic to discover. Thus, the prestige that male athletes accrue is due largely to the collective evaluations and esteem of other men. Women need only be attracted to the most discussed, the richest, the most visible, athletes - and these are filtered through the sieve of male fans, male owners, and male players. Many products from "higher" culture appear to follow a similar pattern.

Consider, for example, Thucydides' History of the Peloponnesian War. It is an exquisite display of cultural and historical learning, cognitive powers, and abundant leisure. Although hard data are impossible to acquire, evidence suggests that Greek women were not highly literate, and they did not receive the formal education that Greek men did (Garland, 2008). Therefore, Thucydides' history does not seem well designed to impress women, most of whom were probably unable to assess its quality. Furthermore, the topics - status, war, heroism, and the operations of male coalitions - that the book covers do not appear well chosen to impress an audience of women. Upon the other hand, those topics, which demonstrate an acute knowledge about the operations of coaltions, political machinations, military financing, and combat, are potentially important to men, especially during a time of conflict, and would therefore win their approbation. Similar arguments hold for many of the great works of antiquity. From Homer's Iliad to Virgil's Aeneid, Plato's Republic to Aristotle's Metaphysics, Caesar's Conquest of Gaul to Cicero's On the Laws, the preponderance of great ancient writings appear designed to elicit the approval and esteem of high status men, not the affections of women. As Classics scholar W. Jeffrey Tatum (2008) put it, "With precious few exceptions, Latin literature and Latin inscriptions were composed by men - and for men [emphasis in original]" (p. 102). The same could be said for Greek literature. Scholars might object that women were harshly oppressed in many ancient societies, leading them to pursue activities and interests out of necessity rather than 
desire. This is certainly true, at least to a degree. But even if it is stipulated that women would be interested in war and competing coalitions without such oppression, it does not change the argument. Men were still writing books that could not have appealed to women.

This pattern is not confined to classical Greece or Rome. Although it is difficult to specify with certainty the exact intended audience of many cultural displays, it is possible to speculate. Such speculations could prove false, but they are not entirely frivolous. For example, most of the great works of philosophy in the Western Canon appear to target men more than women. In fact, some feminists have noted this and have complained that Western philosophy has been dominated by "patriarchal" discourse (e.g., Irigaray, 1985). Others are critical of such contentions (e.g., Hoff Sommers, 1995), but they do suggest that certain qualities about the works of the Western Canon in philosophy appeal more to men, on average, than to women. Many of the great works of history, including Macaulay's and Gibbon's, focus on competing coalitions, ideological conflicts, and political battles, topics that appear designed to display coalitional expertise chiefly to other men (who were the primary power players at the time). Modern pop singers from the Beatles to 'N Sync seem effectively to target teenage women (and men), but a large and motley crew of metal singers and bands (from Black Sabbath to Cannibal Corpse) seem to display aggressiveness and dominance to other men (or rivals) rather than empathy or romantic longing to women. We believe that many past and modern cultural displays follow this pattern, as illustrated in table 2 .

[INSERT TABLE 2 ABOUT HERE]

\section{Alternative Displays?}

But many male poets do write exquisitely tender poems filled with romantic passion; many male novelists write stories about lovers battling against obstacles to reunite or to remain 
together; and many male pop singers croon sensitive tunes about vulnerabilities, passions, and the devastation that accompanies the dissolution of a romantic relationship (Fisher, 1994; Miller, 2000) These cultural displays do not seem particularly well suited to signal traits related to coalitional competition to other men or women. Rather, they seem well designed to signal sensitivity, fidelity, passion, and romantic desire to women. According to the SCM, such displays constitute a small but substantial portion of male ornamental (adornment) cultural displays. That is, the SCM does not argue that all cultural displays are designed to appeal to other high status members of a coalition. Some are almost certainly designed to appeal to the other sex.

Although we have accepted and presented a version of human evolution that emphasizes limited female choice, we do not think women exercised no choice. Because there was at least some degree of mutual mate choice throughout human evolution, men would have evolved proclivities for signaling desirable traits and assets to women such as loyalty, passion, vigor, health, resources, willingness to invest, ability to protect, et cetera (Buss \& Schmitt, 1993; Gallup \& Frederick, 2010; Miller, 2000; Townsend \& Levy, 1990). These can be signaled in cultural displays such as love poetry, romance novels, dramas, love songs, sports cars, luxurious houses, prestigious clothes, et cetera. Of course, many cultural products and displays can signal to both potential coalitional members and to potential lovers simultaneously. However, many such signals are potentially mutually exclusive. Signals of commitment and devotion to a woman might indicate that one is not as committed to a mostly male coalition as one could be. This might explain why some men who signal loyalty, commitment, vulnerability, and sensitivity to women become objects of derision and are tormented by other men (Phoenix, Frosh, \& Pattman, 
2003). For one example, male pop singers, who write and sing treacly love ballads are often blasted by other men (perhaps some of this is because of jealousy).

Although we expect to see men signaling to attract mates through cultural artifacts and displays in all cultures, we predict that the amount of such signaling will vary depending upon several social factors. The intensity of between group conflict, for example, should affect the proportion of signals aimed at potential lovers versus coalitional members. As between group competition increases in intensity, signaling to potential mates should decrease. Furthermore, as sex equality increases, the proportion of signals aimed at potential mates should increase. This might partially explain the remarkable "male beauty contests" (Guérewol) of the Wodaabe. During these ceremonies, men paint their faces with red ochre, adorn their heads with ostrich plumes, outline their eyes with black eyeliner, line their noses with arrow stripes, bare pearl white teeth, and wear beaded necklaces and bodices to jangle with the rhythm of their dance while women assess them for beauty (Beckwith, 1983). Although the Wodaabe do have sex segregation, they appear peaceful—beset by little mortal coalitional conflict. Similar reasoning may apply to modern high schools and colleges. Obviously, more scholarship is needed to refute or corroborate the hypotheses forwarded in this section. Perhaps the most important point is that the SCM does not contend that all signals are aimed at coalitional members (or high status members of coalitions). Many signals appear targeted at potential lovers and mates, as argued by the CCM.

\section{Assessment of Evidence}

The strongest source of difference between the SCM and the CCM is the proposed target audience for ornamental (adornment) displays. The CCM strongly contends that displayers target the other sex with their displays. The SCM, on the other hand, argues that exactly the opposite is 
true of many ornamental (adornment) displays. The evidence is mixed, but suggestive. The CCM inspired a wave of early research that supported its broad framework: men create and display cultural artifacts to woo women. Many of these studies were well done, and they do strongly suggest that men will use cultural displays (including "conspicuous consumption") to allure women. Some studies (e.g., Nelissen and Meijers, 2010) show that both men and women treat those who display prestige goods (name brands) better than those who display plain goods, suggesting that both men and women might target others with prestige goods to obtain status. However, relatively few (see, however, Rucker \& Galinsky, 2008) studies have actually examined the effects of power and status motives (or social competition motives) on men and women's cultural displays.

We believe that a thorough examination of many cultural artifacts and displays across history reveals that many cultural displays are/were designed to appeal to men. This contention, however, is difficult to support with strong data, because, to our knowledge, few researchers have examined this experimentally. The literature of classical Rome and Greece provides especially compelling evidence of this claim, however, because of the disparities in literacy rates and education between men and women (favoring men) and because of the topics of the works. Our other claims — say about the major works of the Western Canon of philosophy—are more difficult to assess. Nevertheless, it appears plausible to argue that such works targeted mainly men; furthermore, it seems implausible that they targeted mainly women.

The CCM might argue, however, that such displays are like a painting. It does not require that one actually like the content of the painting to appreciate its quality. A person might despise King Henry VIII but still recognize the brilliance of a painter's depiction of him. The ultimate, evolutionary purpose of such displays, according to the CCM, is to signal one's underlying 
genetic health. Although women do not care as much for the content as men do, women do care about the form. A good work of political intrigue written during the early days of the Roman Empire might have appealed more to men than to women; however, women could still have assessed the work's quality and found its creator attractive. We believe this argument is flawed. First, as noted above, most works of classical literature were targeted at an elite coterie of educated men. Others could not even read the works. It would be impossible to assess the works without reading them; therefore, many cultural artifacts in history were assessable only by a small, elite group of mostly men.

Second, perhaps the more serious flaw with this argument is the contention that ornamental (adornment) cultural artifacts signal underlying genetic fitness (see section Summing up the Theories). The SCM argues that such displays often signal the immediate possession of important traits or resources, not underlying genetic health. Consider a novel—say, James Joyce's Ulysses (a long, complicated masterpiece of Modernist fiction).The author of Ulysses certainly required an impressive, sophisticated, and powerful mind. It is a complicated novel that makes enigmatic allusions to the entire history of English literature. A brain capable of producing such a work was probably a marvel of organic engineering; therefore, Ulysses probably does suggest something about Joyce's underlying genetic mutation load (Banks, Batchelor, \& McDaniel, 2010). However, Ulysses also required incredible amounts of leisure, learning, and dedication. Furthermore, it most immediately signaled Joyce's encyclopedic knowledge of Western literature and capacity to create marvelous narratives. These immediate skills are valuable to the men and women who defer/red to Joyce.

According to the CCM, the primary function of Ulysses, regardless of the motives of its creator, was to signal underlying genetic health. And this might explain why women would find 
James Joyce attractive (although, we believe that this explanation is problematic). But it can't explain why men would defer to Joyce, praise his brilliance, collect his images, or write prodigiously long biographies about him (see Ellmann, 1966). Men could not and cannot get indirect genetic (they do not "swap genes" with Joyce) benefits from Joyce (an obvious fact about human biology that is worth noting in this context). Therefore, this explanation cannot work for men. However, the contention that cultural products and displays signal immediate (and often functional) traits can explain why men would defer to Joyce after reading his impressive (some would say needlessly abstruse) novel (Richerson \& Boyd, 2004; Henrich \& Gil-White, 2001).

Furthermore, a strong version of the argument that cultural products and displays signal healthy brains would seem to suggest that a gifted but impecunious poet (without status) should be more attractive to the other sex than a relatively unskilled but popular poet. The gifted poet, according to this argument, should be signaling better health than the unskilled but popular poet. And if this is what is attractive about such a display, the gifted poet's display should make him or her more attractive to the other sex than the unskilled displays of the popular poet. On the other hand, the SCM argues that, ceteris paribus, the popular poet would be more attractive to the other sex because the other sex is not directly attracted to his or her displays, but rather to his or her status (which is won through the displays). Although we are not familiar with any evidence that would adjudicate between these hypotheses, we think the SCM's is more plausible. There are many famous writers of mediocre talent who elicit affection from many high value members of the other sex. And there are no shortage of gifted artists who are relatively obscure and who elicit little affection from most members of the other sex. To be sure, this remains speculative. Empirical research is needed to confirm or refute this line of argument. 


\section{Conclusion and Discussion}

\section{Quick Review of Evidence}

We have argued that many researchers in social and evolutionary psychology have relied, either implicitly or explicitly, upon a cultural courtship model to explain the production of cultural artifacts and displays, especially ornamental artifacts and displays. The CCM contends that many cultural artifacts and displays are signals that indicate one's genetic fitness to the other sex. The CCM was a creative explanation of cultural production and instigated a fruitful paradigm of research. However, we have argued that the CCM is largely mistaken about the underlying logic of cultural production and signaling. According to our alternative, the status competition model of cultural production, many cultural artifacts and displays are created to signal the possession of important cultural competencies to other coalitional (or potential coalitional) members to achieve prestige for the producer. These competencies vary from culture to culture and across time. For example, in the Roman Empire, martial prowess may have been an important skill to signal to others, whereas in modern Western societies, empathy and creativity might be important skills to signal. (Creativity was also almost certainly important in Rome.) This variance at least partially explains why different cultures value different artifacts and displays.

We examined two chief sources of evidence. We examined human evolution. And we examined current data, including the likely target of many cultural displays. First, we argued that some version of a social competition theory of human evolution provides a more accurate explanation of brain expansion and increasing cultural complexity than a sexual selection account. According to Miller (2000), the human brain evolved primarily to send signals of underlying genetic health to the other sex. In such an account, intelligence itself is like a gaudy 
cultural display: it is a wasteful and extravagant manifestation of the genes that signals a low mutation load (or a "healthy brain"). Other researchers, however, have posited that humans entered a novel cognitive niche and that social competition (coalitional competition) likely drove the evolution of many unique human traits, including intelligence and an augmented capacity to create culture.

Furthermore, we noted that some modern researchers have questioned the contention that free mate choice, especially free female mate choice, prevailed throughout human evolution. Apostolou (2007; 2010), for example, has documented the strong influence that parents have exerted on their daughters' mate choices. And Puts (2010) has argued that humans are strongly dimorphic on traits (muscularity, for example) that might indicate a history of contest competition between men, with the winners picking the mate (s) of their choice. We contended that most relevant strands of evidence support these basic posits of human evolution. Men and women exhibit small but reliable psychological differences that suggest a history of male coalitional conflict. Specifically, men are stronger systematizers than empathizers (relative to women), are more tolerant of strangers than women, are more likely to take risks than women, are more physically aggressive than women, and support more inequality between groups than women (Geary, 2010). Women, on the other hand, are stronger empathizers than systematizers, are more sensitive to facial expression than men, and are more interested in dyadic or small-scale social interactions than men (Benenson, 2013) Men and women are also dimorphic in reliable and telling ways. Women seem to possess secondary sexual ornaments that are designed to enthrall the other sex (breasts and other gynoid fat distributions, lips, hair, et cetera). Men, upon the other hand, seem to possess secondary sexual characteristics that are designed to intimidate or vanquish competitors. These lines of evidence suggest a history of coalitional combat, male 
contest competition, and limited female mate choice, which support the SCM and contradict or cast doubt on a strong version of the CCM.

Last, we argued that empirical data and careful analysis of many cultural artifacts and displays support the SCM more than the CCM. It is certainly true that some of the CCM's predictions are supported by data. Research has shown that men conspicuously consume more, become more creative, and take more risks when primed with mating motives (or when observed by women) than when in a control condition (or observed by a low status man). Research has also shown that men produce more cultural artifacts and displays (ornamental adornments) when in their 20's and 30's than at any other age, as predicted by Miller (1999) and Kanazawa (2001), using the CCM. However, these predictions do not contradict the SCM, which contends that some cultural displays are aimed at the other sex. The SCM would also predict that men would produce more artifacts and displays when vying for status and prestige in a hierarchy (i.e., when in 20's and 30's). The SCM, however, also predicts that men will continue to produce cultural artifacts and displays even into very old age (if capable) because such displays might enhance their lineages and therefore provide inclusive fitness benefits (e.g., by helping their children and grandchildren).

Other evidence appears to contradict the CCM but support the SCM. Many cultural artifacts and displays that are created by men appear to target other men more than other women. For example, sports predominantly attract men. More men play sports than women. But more men are also interested in sports than women, including the arcane minutia of statistics that assess the productivity of athletes. Many of the cultural productions (especially literature) of Classical Rome and Greece unambiguously follow a similar pattern. In these cultures, only a small group of elite men and women were literate; and more men than women were educated 
enough to properly assess the great works of the Roman and Greek worlds. These works often covered topics that appear to have more intrinsic appeal to men than to women, providing more evidence that they primarily targeted men. More controversially, we speculated that many other works in history followed a similar pattern. That is, they were created by men and displayed to men. This clearly contradicts a central hypothesis of the CCM, but is completely congruent with the SCM. Many feminists have made similar criticisms of the Western world, noting that much of its culture has been created by men and for men. Others, however, have pointed out that women, from Sappho to Madame Curie, made important contributions to the cultural landscape of Western society (Donovan, 2012).

\section{Women and Modern Society}

Throughout this article, we have chiefly focused on ornamental adornments. And we have noted that both the CCM and the SCM predicted that men would produce more ornamental cultural displays than women. However, we also noted that the CCM is congruent with a long evolutionary history of mutual mate choice, and that the SCM does not necessarily predict that men are intrinsically more motivated to produce more cultural artifacts and displays than women. In fact, both the CCM and the SCM predict that women should produce cultural artifacts and displays as well as men, especially as society becomes more sex equal and encourages women to pursue careers outside the home. As far as we can tell, the CCM contends that women should primarily target men with their cultural displays, for the same reason that men should primarily target women. The SCM, on the other hand, contends that women should target those who can confer status in a particular coalition. So, for example, Hillary Clinton's writings or speeches should appeal to the members of a coalition from whom she can obtain status. We did not, however, spend considerable time on the remarkable achievements of women for a few reasons. 
First, despite the rightly lauded achievements of many women, men have controlled society and its cultural institutions for most of history and have therefore produced the bulk of Western culture's (ornamental adornment) artifacts that are displayed. And second, the clearest evidence that supports the SCM while contradicting the CCM is the apparent target of many cultural displays. As we have noted, throughout most of history, it appears that men created many cultural artifacts to impress or intimidate other men. (Again, this does not deny the many astonishing artifacts women have created, from brilliant poems to important scientific discoveries.)

The SCM predicts that as society becomes more peaceful (Pinker, 2011) and traditional coalition conflicts abate (those that are based on physical prowess or martial skills), the avenues for prestige should become more pluralistic because the skills that men and women need to possess and signal become more varied than in more traditional societies (Winegard, Winegard, \& Geary, 2014). We suspect that the modern West, with its relative peace and prosperity, will continue to encourage more women to enter the cultural marketplace, and women will consequently increase their creations and displays of cultural artifacts. This is an argument that many feminists have put forward (Donovan, 2012). The SCM adds a functional explanation to this observation, however. That is, modern societies can benefit more from multifarious skills and talents than more traditional societies. For example, in modern societies, men and women can benefit others by becoming computer programmers, chess champions, painters, poets, retail clerks, musicians, psychologists, statisticians, actors, and comedians, just to name a few. This means that men and women can obtain status by signaling the possession of a wide array of different skills. And this means that men and women should flood to occupy these novel niches.

\section{Prometheus Found}


We began this article with a simple question: Why would evolution birth creatures who would desire to spend precious time creating apparently functionless artifacts such as Kant's The Critique of Pure Reason? We offered a status competition model of cultural production as at least a partial answer. Many ornamental cultural artifacts and displays, according to this model, signal the possession of valuable cultural competencies such as intelligence, erudition, charisma, mathematical ability, et cetera. The men and women who signal such traits are recompensed for their effort with prestige; that is, other men and women willingly defer to them, granting them privileged access to coveted resources. The motivation and desire to create great cultural artifacts, according to this framework, are built from the inglorious and uncelebrated labor of hundreds to thousands of genes. These genes have promoted their own survival and replication by creating animals that desire to produce cultural artifacts. The Promethean fire of civilization is nourished by the fitness advantages that accrue to cultural producers. It is not from the benevolence of Bach or Beethoven that one expects his or her music. Cultural creators offer their gifts to civilization in exchange for esteem. And this trade keeps the business of culture genetically profitable. 


\section{References}

Addison, W. E. (1989). Beardedness as a factor in perceived masculinity. Perceptual and Motor Skills, 68, 921-922.

Agrawal, A. F., \& Whitlock, M. C. (2012). Mutation load: the fitness of individuals in populations where deleterious alleles are abundant. Annual Review of Ecology, Evolution, and Systematics, 43, 115-135.

Aiello, L. C., \& Wheeler, P. (1995). The expensive-tissue hypothesis: the brain and the digestive system in human and primate evolution. Current anthropology, 36, 199- 221.

Alexander, R. D. (1990). How did humans evolve? Reflections on the uniquely unique species. Ann Arbor: University of Michigan.

Anderson, C., \& Kennedy, J. A. (2012). Micropolitics: A new model of status hierarchies in teams. Research on Managing Groups and Teams, 15, 49-80.

Anderson, C., \& Kilduff, G.J. (2009). The pursuit of status in social groups. Current Directions in Psychological Science, 18, 295-298.

Anderson, E. (2000). Code of the street: Decency, violence, and the moral life of the inner city. New York: WW Norton \& Company.

Apostolou, M. (2007). Sexual selection under parental choice: The role of parents in the evolution of human mating. Evolution and Human Behavior, 28, 403-409.

Apostolou, M. (2010). Sexual selection under parental choice: Evidence from sixteen historical societies. Evolutionary Psychology, 10, 504-518.

Baker Jr, M. D., \& Maner, J. K. (2008). Risk-taking as a situationally sensitive male mating strategy. Evolution and Human Behavior, 29, 391-395. 
Banks, G. C., Batchelor, J. H., \& McDaniel, M. A. (2010). Smarter people are (a bit) more symmetrical: A meta-analysis of the relationship between intelligence and fluctuating asymmetry. Intelligence, 38, 393-401.

Barnes, C. D., Brown, R. P., \& Tamborski, M. (2012). Living dangerously: Culture of honor, risk-Taking, and the nonrandomness of "accidental" deaths. Social Psychological and Personality Science, 3, 100-107.

Barnes, C. D., Brown, R. P., \& Osterman, L. L. (2012). Don't tread on me: Masculine honor ideology in the US and militant responses to terrorism. Personality and Social Psychology Bulletin, 38, 1018-1029.

Baron-Cohen, S., Richler, J., Bisarya, D., Gurunathan, N., \& Wheelwright, S. (2003). The systemizing quotient: an investigation of adults with Asperger syndrome or highfunctioning autism, and normal sex differences. Philosophical Transactions of the Royal Society of London. Series B: Biological Sciences, 358, 361-374.

Baumeister, R.F. (2005). The cultural animal: Human nature, meaning, and social life. New York: Oxford University Press.

Baumeister, R.F. (2010). Is there anything good about men? How cultures flourish by exploiting men. New York: Oxford University Press.

Beckwith, C. (1983). Niger's Wodaabe: "People of the taboo." National Geographic, 164, 483509.

Benenson, J.F. (2014). Warriors and worriers: The survival of the sexes. New York: Oxford University Press.

Berreby, D. (2005). Us and them: Understanding your tribal mind. New York: Little, Brown and Company. 
Bereczkei, T., Birkas, B., \& Kerekes, Z. (2007). Public charity offer as a proximate factor of evolved reputation-building strategy: an experimental analysis of a real-life situation. Evolution and Human Behavior, 28, 277-284

Bingham, P. M. (1999). Human uniqueness: a general theory. Quarterly Review of Biology, 74, 133-169.

Buss, D.M. (2008). Evolutionary psychology: The new science of the mind ( $3^{\text {rd }}$ ed.). Boston, MA: Pearson.

Buss, D. M., \& Schmitt, D. P. (1993). Sexual strategies theory: An evolutionary perspective on human mating. Psychological Review, 100, 204-232.

Cant, J. G. (1981). Hypothesis for the evolution of human breasts and buttocks. American Naturalist, 117, 199-204.

Carney, D. R., Jost, J. T., Gosling, S. D., \& Potter, J. (2008). The secret lives of liberals and conservatives: Personality profiles, interaction styles, and the things they leave behind. Political Psychology, 29, 807-840.

Cash, T. F., Dawson, K., Davis, P., Bowen, M., \& Galumbeck, C. (1989). Effects of cosmetics use on the physical attractiveness and body image of American college women. The Journal of Social Psychology, 129, 349-355.

Cecil, E. (1895). Primogeniture: a short history of its development in various countries and its practical effects. London: John Murray.

Chapais, B. (2008). Primeval kinship: How pair-bonding gave birth to human society. Cambridge, MA: Harvard University Press.

Chapais, B. (2013). Monogamy, strongly bonded groups, and the evolution of human social structure. Evolutionary Anthropology, 22, 52-65. 
Dastrup, S. R., Graff Zivin, J., Costa, D. L., \& Kahn, M. E. (2012). Understanding the solar home price premium: electricity generation and "green" social status. European Economic Review, 56, 961-973.

Davies, S. (2006). Aesthetic judgements, artworks and functional beauty. The Philosophical Quarterly, 56, 224-241.

Davis, K., \& Moore, W. E. (1945). Some principles of stratification. American Sociological Review, 10, 242-249.

Davis, N. W., \& Duncan, M. C. (2006). Sports knowledge is power: Reinforcing masculine privilege through fantasy sport league participation. Journal of Sport \& Social Issues, 30, 244-264.

Darwin, C. (1958). On the origin of species by means of natural selection. New York: New American Library. (Original work published 1859).

Darwin, C. R. (1871). The descent of man, and selection in relation to sex. London: John Murray.

Dissanayake, E. (1990). What is art for? Seattle, WA: University of Washington Press.

Deacon, T. W. (1997). The symbolic species: The co-evolution of language and the human brain. New York, NY: Norton.

Deaner, R. O., Geary, D. C., Puts, D. A., Ham, S. A., Kruger, J., Fles, E., Winegard, B., \& Grandis, T. (2012). A sex difference in the predisposition for physical competition: males play sports much more than females even in the contemporary US. PloS one, 7, e49168.

Deaner, R., \& Smith, B. (2013). Sex differences in sports across 50 societies. Cross-cultural Research, 47, 268-309. 
Dixson, B. J., \& Vasey, P. L. (2012). Beards augment perceptions of men's age, social status, and aggressiveness, but not attractiveness. Behavioral Ecology, 23, 481-490.

Dunn, M. J., \& Searle, R. (2010). Effect of manipulated prestige-car ownership on both sex attractiveness ratings. British Journal of Psychology, 101, 69-80.

Dunn, M. J., \& Hill, A. (2014). Manipulated luxury-apartment ownership enhances opposite-sex attraction in females but not males. Journal of Evolutionary Psychology, 12, 1-17.

Ellmann, R. (1966). James Joyce. New York: Oxford University Press.

Elton, S., Bishop, L. C., \& Wood, B. (2001). Comparative context of Plio-Pleistocene hominin brain evolution. Journal of Human Evolution, 41, 1-27.

.Etcoff, N. L., Stock, S., Haley, L. E., Vickery, S. A., \& House, D. M. (2011). Cosmetics as a feature of the extended human phenotype: Modulation of the perception of biologically important facial signals. PloS one, 6, e25656.

Falk, D., Redmond Jr, J. C., Guyer, J., Conroy, C., Recheis, W., Weber, G. W., \& Seidler, H. (2000). Early hominid brain evolution: a new look at old endocasts. Journal of Human Evolution, 38, 695-717.

Farquhar, L. K., \& Meeds, R. (2007). Types of fantasy sports users and their motivations. Journal of Computer-Mediated Communication, 12, 1208-1228.

Farrelly, D., \& Nettle, D. (2007). Marriage affects competitive performance in male tennis players. Journal of Evolutionary Psychology, 5, 141-148.

Fisher, H. E. (1994). Anatomy of love: A natural history of mating, marriage, and why we stray. New York, NY: Random House. 
Flinn, M. V., Geary, D. C., \& Ward, C. V. (2005). Ecological dominance, social competition, and coalitionary arms races: Why humans evolved extraordinary intelligence. Evolution and Human Behavior, 26, 10-46.

Foley, R., \& Lahr, M. M. (2003). On stony ground: lithic technology, human evolution, and the emergence of culture. Evolutionary Anthropology: Issues, News, and Reviews, 12, 109122.

Frankenhuis, W. E., Dotsch, R., Karremans, J. C., \& Wigboldus, D. H. (2010). Male physical risk taking in a virtual environment. Journal of Evolutionary Psychology, 8, 75-86.

Frederick, D. A., \& Haselton, M. G. (2007). Why is muscularity sexy? Tests of the fitness indicator hypothesis. Personality and Social Psychology Bulletin, 33, 1167-1183.

Gallup Jr, G. G., \& Frederick, D. A. (2010). The science of sex appeal: An evolutionary perspective. Review of General Psychology, 14, 240-250.

Garland, R. (2008). Daily life of the Ancient Greeks. Indianapolis, IN: Hackett.

Geary, D.C. (2005). The origin of mind: Evolution of brain, cognition, and general intelligence. Washington, DC: American Psychological Association

Geary, D.C. (2010). Male/female: The evolution of human sex differences $\left(2^{\text {nd }}\right.$ ed.). Washington, DC: American Psychological Association.

Geary, D. C., \& Flinn, M. V. (2001). Evolution of human parental behavior and the human family. Parenting, 1, 5-61.

Gilmore D.D. (1990). Manhood in the making. New Haven, CT: Yale University Press

Goldberg, S. (1999). Why men rule: A theory of male dominance. Chicago: Open Court. 
Griskevicius, V., Cialdini, R. B., \& Kenrick, D. T. (2006). Peacocks, Picasso, and Parental investment: The effects of romantic motives on creativity. Journal of Personality and Social Psychology, 91, 63-76.

Griskevicius, V., Tybur, J. M., Sundie, J. M., Cialdini, R. B., Miller, G. F., \& Kenrick, D. T. (2007). Blatant benevolence and conspicuous consumption: when romantic motives elicit strategic costly signals. Journal of Personality and Social Psychology, 93, 85-102.

Guéguen, N., Meineri, S., \& Fischer-Lokou, J. (2014). Men's music ability and attractiveness to women in a real-life courtship context. Psychology of Music, 42, 545-549.

Guttman, A. (1986). Sports spectators. New York, NY: Columbia University Press.

Guttman, A. (2007). Sports: The first five millennia. Amherst, MA: University of Massachusetts Press.

Hardy, C. L., \& Van Vugt, M. (2006). Nice guys finish first: The competitive altruism hypothesis. Personality and Social Psychology Bulletin, 32, 1402-1413.

Henrich, J., \& Gil-White, F. J. (2001). The evolution of prestige: Freely conferred deference as a mechanism for enhancing the benefits of cultural transmission. Evolution and Human Behavior, 22, 165-196.

Hill, K. R., Walker, R. S., Božičević, M., Eder, J., Headland, T., Hewlett, B., Hurtado, A.M., Marlow, F., Wiessner, P., \& Wood, B. (2011). Co-residence patterns in hunter-gatherer societies show unique human social structure. Science, 331, 1286- 1289.

Hodges-Simeon, C. R., Gaulin, S. J., \& Puts, D. A. (2011). Voice correlates of mating success in men: Examining "contests" versus "mate choice" modes of sexual selection. Archives of Sexual Behavior, 40, 551-557. 
Hoff Sommers, C. (1995). Who stole feminism? How women have betrayed women. New York: Simon \& Schuster.

Hofstede, G. (2003). What is culture? A reply to Baskerville. Accounting, Organizations and Society, 28, 811-813.

Hooper, P. L., \& Miller, G. F. (2008). Mutual mate choice can drive costly signaling even under perfect monogamy. Adaptive Behavior, 16, 53-70.

Howlett, N., Pine, K., Orakçioglu, I., \& Fletcher, B. (2013). The influence of clothing on first impressions: Rapid and positive responses to minor changes in male attire. Journal of Fashion Marketing and Management, 17, 38-48.

Hudders, L., De Backer, C., Fisher, M., \& Vyncke, P. (2014). The rival wears Prada: Luxury consumption as a female competition strategy. Evolutionary Psychology, 12, 570-587.

Humphrey, N.K. (1976). The social function of intellect. In P. Bateson \& R. Hinde (Eds.). Growing points in ethology (pp. 303-317). Cambridge: Cambridge University Press.

Irigaray, L. (1985). Speculum of the Other Woman. Ithaca, NY: Cornell University Press.

Irons, W. (1979). Cultural and biological success. In N. A. Chagnon \& W. Irons (Eds.), Natural selection and social behavior (pp. 257-272). North Scituate, MA: Duxbury Press.

Jackson, T. T., \& Gray, M. (1976). Field study of risk-taking behavior of automobile drivers. Perceptual and Motor Skills, 43, 471-474.

Jaeggi, A. V., Burkart, J. M., \& Van Schaik, C. P. (2010). On the psychology of cooperation in humans and other primates: combining the natural history and experimental evidence of prosociality. Philosophical Transactions of the Royal Society B: Biological Sciences, $365,2723-2735$. 
James, J.D. (2001). The role of cognitive development and socialization in the initial development of team ingroup loyalty. Leisure Sciences, 23, 233-261.

James, J.D., and Ridinger, L.L. (2002). Female and male sports fans: A comparison of motives. Journal of Sport Behavior, 25, 260-278.

Jasieńska, G., Ziomkiewicz, A., Ellison, P. T., Lipson, S. F., \& Thune, I. (2004). Large breasts and narrow waists indicate high reproductive potential in women. Proceedings of the Royal Society B: Biological Sciences, 271, 1213-1217.

Jobling, M. A. (2001). In the name of the father: surnames and genetics. Trends in Genetics, 17 , 353-357.

Kanazawa, S. (2000). Scientific discoveries as cultural displays: a further test of Miller's courtship model. Evolution and Human Behavior, 21, 317-321.

Klein, R. (2009). The human career: Human biological and cultural origins (3rd ed.). Chicago: University of Chicago Press.

Kirchner, P. (2004). Dueling with the sword and pistol: 400 years of one-on-one combat. Boulder, Co: Paladin Press.

Kohn, M., \& Mithen, S. (1999). Handaxes: products of sexual selection? Antiquity, 73, 518-526.

Kroeber, A. L., \& Parsons, T. (1958). The concepts of culture and of social system. American Sociological Review, 23, 582-583.

Kuehn, M. (2001). Kant: A biography. New York, NY: Cambridge University Press.

Kyle, D. J., \& Mahler, H. I. (1996). The effects of hair color and cosmetic use on perceptions of a female's ability. Psychology of Women Quarterly, 20, 447-455 
Lassek, W. D., \& Gaulin, S. J. (2009). Costs and benefits of fat-free muscle mass in men: relationship to mating success, dietary requirements, and native immunity. Evolution and Human Behavior, 30, 322-328.

Lombardo, M. P. (2012). On the evolution of sport. Evolutionary Psychology,10, 1-28.

Lycett, S. J., Collard, M., \& McGrew, W. C. (2009). Cladistic analyses of behavioural variation in wild Pan troglodytes: exploring the chimpanzee culture hypothesis. Journal of Human Evolution, 57, 337-349.

Malinowski, B. (1944). A scientific theory of culture, and other essays. Chapel Hill, NC: University of North Carolina Press.

Marlowe, F. (1998). The nubility hypothesis. Human Nature, 9, 263-271.

Marlowe, F. W. (2005). Hunter-gatherers and human evolution. Evolutionary Anthropology: Issues, News, and Reviews, 14, 54-67.

Manning, J. T., \& Taylor, R. P. (2001). Second to fourth digit ratio and male ability in sport: Implications for sexual selection in humans. Evolution and Human Behavior, 22, 61-69.

McBrearty, S., \& Brooks, A. S. (2000). The revolution that wasn't: a new interpretation of the origin of modern human behavior. Journal of human evolution, 39, 453- 563.

Miller, G.F. (1999). Sexual selection for cultural displays. In R. Dunbar, C. Knight, \& C. Power (Eds.), The evolution of culture (pp. 71-91). New Brunswick: Rutgers University Press.

Miller, G. F. (2000). The mating mind: How sexual choice shaped the evolution of human nature. New York, NY: Doubleday.

Miller, G. F. (2001). Aesthetic fitness: How sexual selection shaped artistic virtuosity as a fitness indicator and aesthetic preferences as mate choice criteria. Bulletin of Psychology and the Arts 2, 20-25. 
Miller, G.F. (2010). Spent: Sex, evolution, and consumer behavior. New York, NY: Penguin.

Miller, G.F. (2013). Mutual mate choice models as the red pill in evolutionary psychology: long delayed, much needed, ideologically challenging, and hard to swallow. Psychological Inquiry, 24, 207-210.

Muscarella, F., \& Cunningham, M. R. (1996). The evolutionary significance and social perception of male pattern baldness and facial hair. Ethology and Sociobiology, 17, 99117.

Neave, N., \& Shields, K. (2008). The effects of facial hair manipulation on female perceptions of attractiveness, masculinity, and dominance in male faces. Personality and Individual Differences, 45, 373-377.

Nelissen, R., \& Meijers, M. H. (2011). Social benefits of luxury brands as costly signals of wealth and status. Evolution and Human Behavior, 32, 343-355.

Nesse, R. M. (2007). Runaway social selection for displays of partner value and altruism. Biological Theory, 2, 143-155.

Nesse, R. M. (2009). Social selection and the origins of culture. In M. Schaller, S. J. Heine, A. Norenzayan, T. Yamagishi, \& T. Kameda (Eds.), Evolution, culture, and the human mind (pp. 137-150). Philadelphia, PA: Lawrence Erlbaum Associates.

Nisbett, R.E., \& Cohen, D. (1996). Culture of honor: The psychology of violence in the South. Boulder, CO: Westview Press.

Norenzayan, A., \& Shariff, A. F. (2008). The origin and evolution of religious prosociality. Science, 322, 58-62.

Nuyts, E. \& Vesentini, L. (2005): The relation between seat belt use of drivers and passengers. In: D. de Waard, K.A. Brookhuis, R. van Egmond \& Th. Boersma (eds): Human factors 
in design, safety, and management. Maastricht, the Netherlands: Shaker Publishing, pp. $1-11$.

Perusse, D. (1993). Cultural and reproductive success in industrial societies: Testing the relationship at the proximate and ultimate levels. Behavioral and Brain Sciences, 16, 267-283.

Phoenix, A., Frosh, S., \& Pattman, R. (2003). Producing contradictory masculine subject positions: Narratives of threat, homophobia and bullying in 11-14 year old boys. Journal of Social Issues, 59, 179-195.

Pinker, S. (2010). The cognitive niche: Coevolution of intelligence, sociality, and language. Proceedings of the National Academy of Sciences, 107, 8993-8999.

Polk, K. (1999). Males and honor contest violence. Homicide Studies, 3, 6-29.

Pratto, F., Stallworth, L. M., \& Sidanius, J. (1997). The gender gap: Differences in political attitudes and social dominance orientation. British Journal of Social Psychology, 36, 4968.

Price, M. E., \& Van Vugt, M. (2014). The evolution of leader-follower reciprocity: The theory of service-for-prestige. Frontiers in Human Neuroscience, 8, 363.

Puts, D. A. (2010). Beauty and the beast: Mechanisms of sexual selection in humans. Evolution and Human Behavior, 31, 157-175.

Puts, D. A., Jones, B. C., \& DeBruine, L. M. (2012). Sexual selection on human faces and voices. Journal of Sex Research, 49, 227-243.

Richerson, P.J., \& Boyd, R. (2004). Not by genes alone: How culture transformed human evolution. Chicago, IL: University of Chicago Press. 
Riddley, M. (1993). The red queen: Sex and the evolution of human nature. New York, NY: Harper.

Robinson, D. E. (1976). Fashions in shaving and trimming of the beard: The men of the Illustrated London News, 1842-1972. American Journal of Sociology, 81, 1133-1141.

Ronay, R., \& von Hippel, W. (2010). The presence of an attractive woman elevates testosterone and physical risk taking in young men. Social Psychological and Personality Science, 1, $57-64$.

Rubenstein, D. R. (2012). Family feuds: Social competition and sexual conflict in complex societies. Philosophical Transactions of the Royal Society B: Biological Sciences, 367, 2304-2313.

Rucker, D. D., \& Galinsky, A. D. (2008). Desire to acquire: Powerlessness and compensatory consumption. Journal of Consumer Research, 35, 257-267.

Rushton, J. P., \& Ankney, C. D. (2009). Whole brain size and general mental ability: a review. International Journal of Neuroscience, 119, 692-732.

Saad, G., \& Vongas, J. G. (2009). The effect of conspicuous consumption on men's testosterone levels. Organizational Behavior and Human Decision Processes, 110, 80-92.

Schwartz, S. H., \& Rubel-Lifschitz, T. (2009). Cross-national variation in the size of sex differences in values: effects of gender equality. Journal of Personality and Social Psychology, 97, 171-185.

Sexton, S. E., \& Sexton, A. L. (2014). Conspicuous conservation: The Prius halo and willingness to pay for environmental bona fides. Journal of Environmental Economics and Management, 67, 303-317. 
Smith, B. H., \& Tompkins, R. L. (1995). Toward a life history of the Hominidae. Annual Review of Anthropology, 257-279.

Sosis, R., Kress, H. C., \& Boster, J. S. (2007). Scars for war: Evaluating alternative signaling explanations for cross-cultural variance in ritual costs. Evolution and Human Behavior, $28,234-247$

Stewart-Williams, S., \& Thomas, A. G. (2013). The ape that thought it was a peacock: Does evolutionary psychology exaggerate human sex differences? Psychological Inquiry, 24, 137-168.

Su, R., Rounds, J., \& Armstrong, P.I. (2009). Men and things, women and people: A metaanalysis of sex differences in interests. Psychological Bulletin, 135, 859- 864.

Sundie, J. M., Kenrick, D. T., Griskevicius, V., Tybur, J. M., Vohs, K. D., \& Beal, D. J. (2011). Peacocks, Porsches, and Thorstein Veblen: conspicuous consumption as a sexual signaling system. Journal of Personality and Social Psychology, 100, 664-680.

Tatum, W.J. (2008). Always I am Caesar. Malden, MA: Blackwell.

Tooby, J., \& DeVore, I. (1987). The reconstruction of hominid behavioral evolution through strategic modeling. In W. G. Kinzey (Ed.). The evolution of human behavior: Primate models (pp. 183-237). New York, NY: State University of New York Press.

Townsend, J. M., \& Levy, G. D. (1990). Effects of potential partners' costume and physical attractiveness on sexuality and partner selection. The Journal of Psychology, 124, 371389.

Trivers, R. L. (1971). The evolution of reciprocal altruism. Quarterly review of biology, 35-57. Van Vugt, M., \& Iredale, W. (2012). Men behaving nicely: Public goods as peacock tails. British Journal of Psychology, 104, 3-13. 
Vigil, J. D. (1996). Street baptism: Chicano gang initiation. Human Organization, 55, 149-153.

Wang, Y., \& Griskevicius, V. (2014). Conspicuous Consumption, Relationships, and Rivals: Women's Luxury Products as Signals to Other Women. Journal of Consumer Research, $40,834-854$.

Wells, C. A. (2001). End of the affair: Anti-dueling laws and social norms in Antebellum America. The Vanderbilt Law Review, 54, 1805-1847.

West-Eberhard, M. J. (1979). Sexual selection, social competition, and evolution. Proceedings of the American Philosophical Society, 123, 222-234.

West-Eberhard, M. J. (1983). Sexual selection, social competition, and speciation. Quarterly Review of Biology, 58, 155-183.

Willer, R. (2009). Groups reward individual sacrifice: The status solution to the collective action problem. American Sociological Review, 74, 23-43.

Willer, R., Rogalin, C. L., Conlon, B., \& Wojnowicz, M. T. (2013). Overdoing Gender: A Test of the Masculine Overcompensation Thesis. American journal of sociology, 118, 9801022.

Williams, G.C. (1966). Adaptation and natural selection. Princeton, New Jersey: Princeton University Press.

Wilson, M., \& Daly, M. (1985). Competitiveness, risk taking, and violence: The young male syndrome. Ethology and Sociobiology, 6, 59-73.

Windhager, S., Schaefer, K., \& Fink, B. (2011). Geometric morphometrics of male facial shape in relation to physical strength and perceived attractiveness, dominance, and masculinity. American Journal of Human Biology, 23, 805-814. 
Winegard, B., \& Deaner, R.O. (2010). The evolutionary significance of Red Sox Nation: Sport fandom as a by-product of coalitionary psychology. Evolutionary Psychology, 8, 432446.

Winegard, B. M., Winegard, B., \& Geary, D. C. (2013). If you've got it, flaunt it: Humans flaunt attractive partners to enhance their status and desirability. PloS one, 8, e72000.

Winegard, B. M., Reynolds, T., Baumeister, R. F., Winegard, B., \& Maner, J. K. (2014). Grief functions as an honest indicator of commitment. Personality and Social Psychology Review, 18, 168-186.

Winegard, B., Winegard, B., \& Geary, D. C. (2014). Eastwood's brawn and Einstein's brain: An evolutionary account of dominance, prestige, and precarious manhood. Review of General Psychology, 18, 34-48. 


\section{Footnotes}

${ }_{1}$ This might not be explicitly popular in the evolutionary literature (although it has certainly inspired research). Rather, we suspect that many scholars implicitly accept some version of the cultural courtship model. We also suspect, as we will note several times, that many researchers and popularizers accept a crude version of the cultural courtship model, one that is inconsistent with Miller's (1999; 2000) original proposal.

${ }_{2}$ This description of the cultural courtship model was simplified to achieve expository clarity and to present a clear alternative to the status competition model of cultural production. The researchers who presented and have supported the CCM do not argue that all cultural productions and cultural displays are ultimately reducible to courtships displays (Miller, 2010). Miller and others have eloquently argued that consumer products and other cultural displays can be used to signal to potential allies, to kin, and to enemies as well as to potential mates. However, the emphasis of the CCM is clearly on motivations to allure the other sex. And that emphasis, we argue, is at least partially misplaced. To a large degree, therefore, our disagreement with the CCM is a matter of emphasis. And, in fact, the SCM can be seen as an augmentation of the CCM rather than an alternative.

${ }_{3}$ We suspect, along with Miller (2013) and Stewart-Williams and Thomas (2013), that many evolutionary psychologists have imbibed a crude version of the CCM. In this version, men compete vigorously for access to sexual partners, whereas women calmly and coolly assess the outcomes of such competitions and displays. It is very important to stress that this crude version of the CCM is not the version of the CCM that Miller endorses or proposed. However, because it is a version that remains popular, we may sometimes suggest that the CCM is cruder and more sex differentiated than it was in the more sophisticated writings of Miller $(2000 ; 2010)$. 
${ }_{4}$ Of course, women made many important contributions to civilization despite their subordinate status throughout most of history. We will discuss this further in the conclusion. However, we focus mostly on men's cultural artifacts and displays in this section because (1) men did create more artifacts and displays for most of history and (2) the fact that men's displays appear to target mostly other men is a clear contradiction of one of the tenets of the CCM. 
Figure 1: A division of cultural displays and products (artifacts)

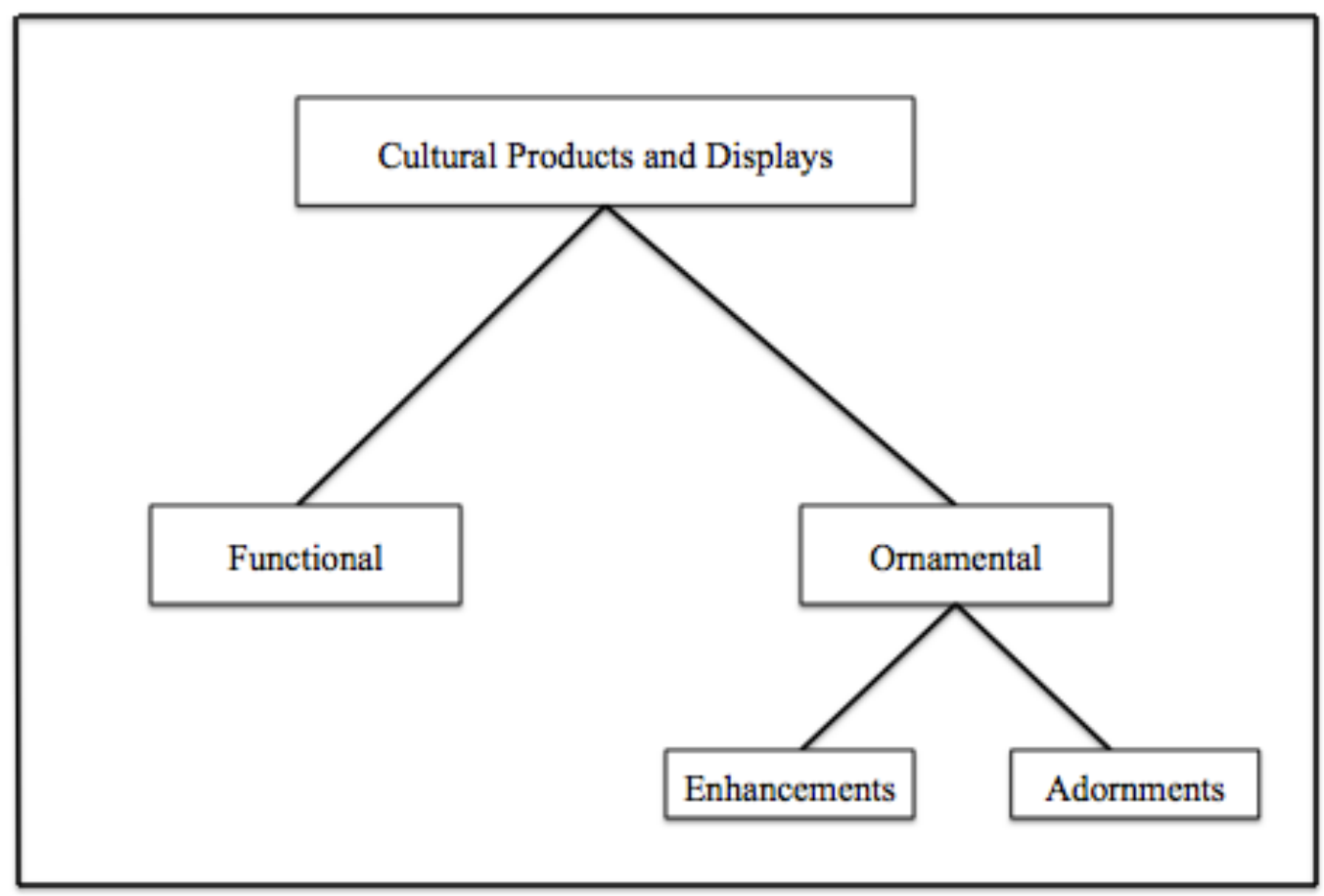

Figure 1: Caption: Cultural displays can be divided into two large categories: functional and ornamental. Functional artifacts solve practical needs. Ornamental artifacts are largely aesthetic (not functional). This division is not, however, either/or. Ornamental displays can be further divided into enhancements and adornments. Any of these artifacts or displays can function as an identifier, or an artifact or display that signals one's allegiance to a group (real or symbolic). 
Figure 2: Functional and ornamental continuum

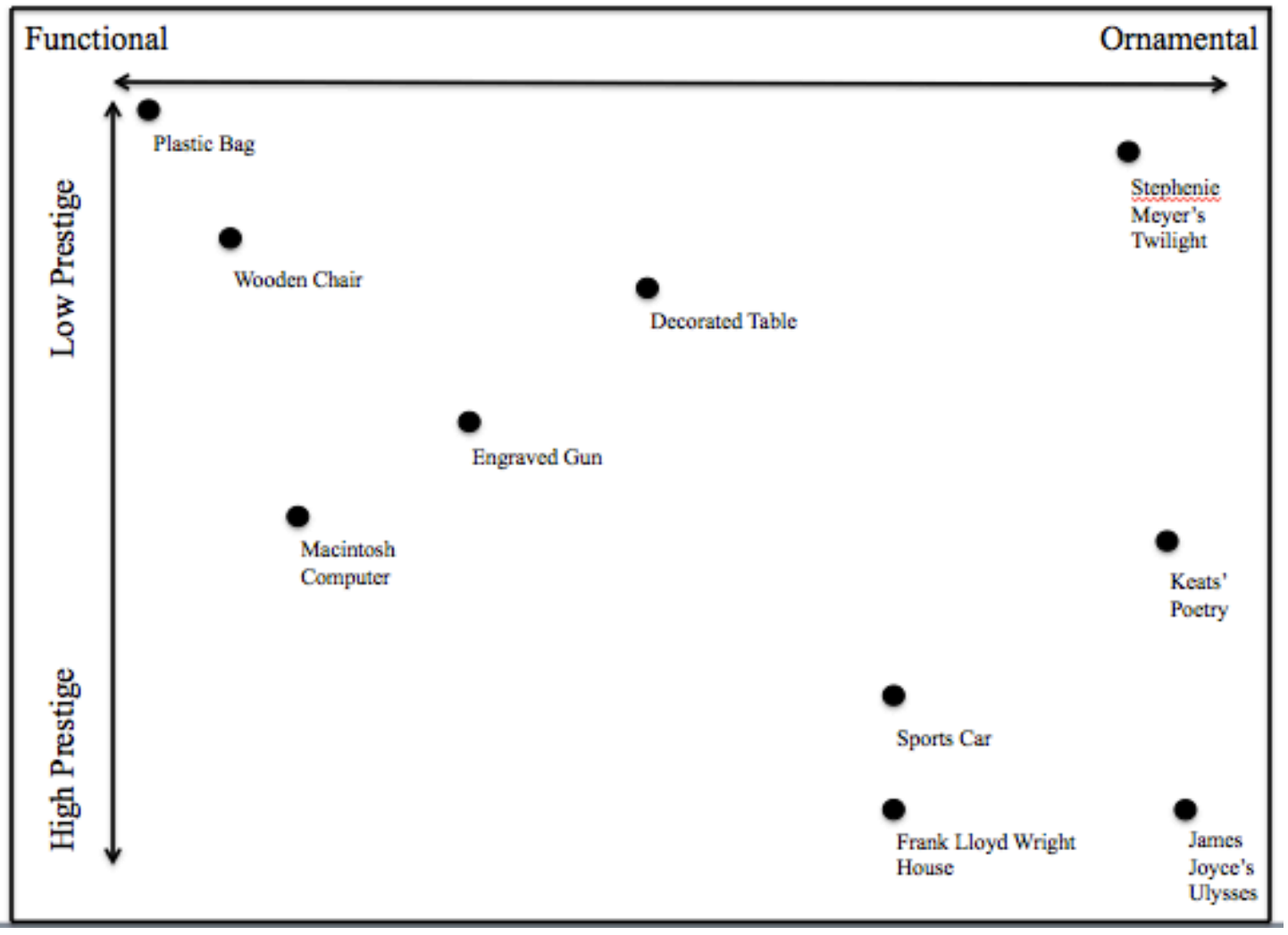

Figure 2: Caption: An example distribution of high prestige and low prestige functional and ornamental artifacts. This is a continuum. As one goes from left to right, the artifact becomes more ornamental. As one goes from top to bottom, the artifact becomes more prestigious. 
Figure 3. The cultural courtship model and the status competition model

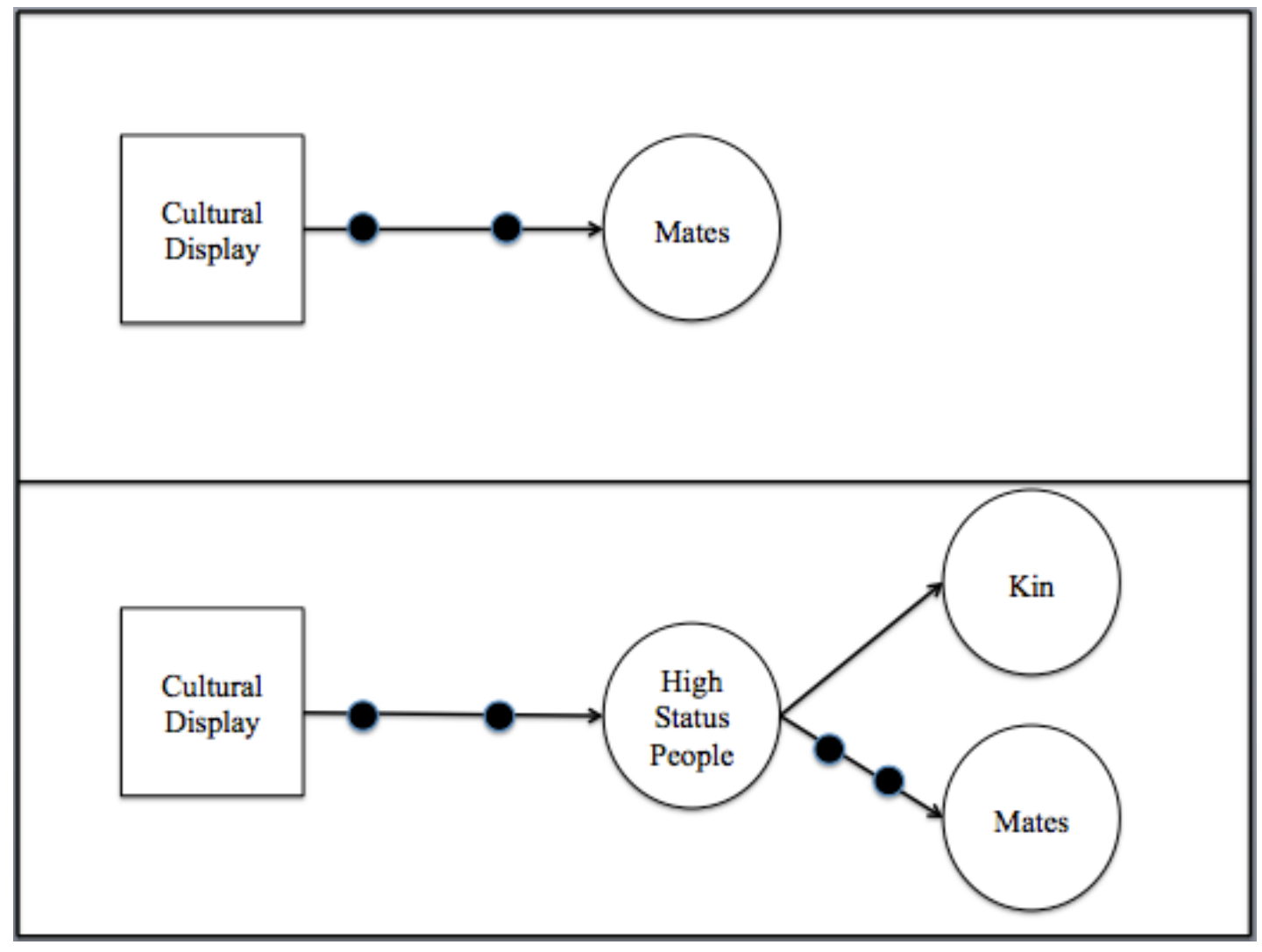

Figure 3: Caption: The top represents the cultural courtship model (CCM) and the bottom represents the status competition model $(\mathrm{SCM})$. Two dots $=$ signal. Line without dots $=$ investment. In the CCM, a cultural display signals to the other sex. In the SCM, a cultural display signals to high status others (or those who can confer status). That status can then be signaled to the other sex or invested in kin. 
Table 1

The Cultural Courtship Model and the Status Competition Model: Basic theory and predictions

\begin{tabular}{|c|c|c|}
\hline & Cultural Courtship (CCM) & Status Competition (SCM) \\
\hline $\begin{array}{l}\text { Chief target of } \\
\text { cultural display }\end{array}$ & $\begin{array}{l}\text { Members of other sex from } \\
\text { signaler }\end{array}$ & $\begin{array}{l}\text { High status peers or others who can } \\
\text { provide prestige }\end{array}$ \\
\hline $\begin{array}{l}\text { What cultural } \\
\text { display signals }\end{array}$ & Genetic Fitness & $\begin{array}{l}\text { Possession of culturally important } \\
\text { competencies (e.g., mathematical } \\
\text { knowledge, coalitional expertise, et } \\
\text { cetera) }\end{array}$ \\
\hline $\begin{array}{l}\text { Evolutionary } \\
\text { model }\end{array}$ & $\begin{array}{l}\text { Free mutual mate choice/ } \\
\text { Possibly, the brain is a } \\
\text { sexually selected organ } \\
\text { signaling genetic fitness to } \\
\text { others }\end{array}$ & $\begin{array}{l}\text { Male contest competition/Coalitional } \\
\text { battles/Relatively unfree mate choice for } \\
\text { most of evolutionary history }\end{array}$ \\
\hline $\begin{array}{l}\text { Chief } \\
\text { predictions }\end{array}$ & $\begin{array}{l}\text { Many artifacts and displays } \\
\text { will appeal to the other sex } \\
\text { Men will produce more } \\
\text { (public) cultural displays and } \\
\text { artifacts than women } \\
\text { Men will produce more } \\
\text { (public) artifacts during their } \\
\text { 20's and 30's than earlier or } \\
\text { later } \\
\text { Women will be attracted to } \\
\text { cultural displayers (regardless } \\
\text { of the displayers' status) }\end{array}$ & $\begin{array}{l}\text { Many artifacts and displays will appeal to } \\
\text { those who can confer status (often men) } \\
\text { Men will produce more (public) cultural } \\
\text { displays and artifacts than women } \\
\text { Women will be attracted to high status } \\
\text { cultural displayers } \\
\text { Men will produce more (public) artifacts } \\
\text { during their 20's and 30's than earlier or } \\
\text { later } \\
\text { Men will be attracted to many cultural } \\
\text { artifacts and displays more than women }\end{array}$ \\
\hline
\end{tabular}


Table 2

Some representative cultural displays/signals and their likely signaling logic

\begin{tabular}{|c|c|c|c|c|}
\hline Signaler & Signal & $\begin{array}{l}\text { Underlying } \\
\text { Quality }\end{array}$ & Probable Audience & References \\
\hline Men & Beard & $\begin{array}{l}\text { Maturity, } \\
\text { Dominance, } \\
\text { Aggressiveness }\end{array}$ & $\begin{array}{l}\text { Other Men. (Women } \\
\text { prefer clean shaven } \\
\text { men or light stubble. } \\
\text { Note: facial hair has } \\
\text { declined in US and etc. } \\
\text { over last century.) }\end{array}$ & $\begin{array}{l}\text { Addison (1989); } \\
\text { Dixson \& Vasey } \\
\text { (2012); Muscarella } \\
\text { \& Cunningham } \\
\text { (1996); Neave \& } \\
\text { Shields (2008); } \\
\text { Robinson (1976) }\end{array}$ \\
\hline $\begin{array}{l}\text { Primarily } \\
\text { Men }\end{array}$ & $\begin{array}{l}\text { Sports' Play } \\
\text { and Fandom }\end{array}$ & $\begin{array}{l}\text { Athleticism, } \\
\text { Aggressiveness, } \\
\text { Dominance, } \\
\text { Loyalty, Pain } \\
\text { Tolerance, } \\
\text { Leadership } \\
\text { Ability, Physical } \\
\text { Competitiveness }\end{array}$ & $\begin{array}{l}\text { Other Men. (Men } \\
\text { appear the chief } \\
\text { audience for athletic } \\
\text { displays, but they are } \\
\text { not the sole audience.) }\end{array}$ & $\begin{array}{l}\text { Lombardo (2012); } \\
\text { Manning \& Taylor } \\
\text { (2001); Winegard } \\
\text { \& Deaner (2010) }\end{array}$ \\
\hline Men & A man's mate & $\begin{array}{l}\text { Social Status, } \\
\text { Desirability }\end{array}$ & $\begin{array}{l}\text { Other Men. (Men } \\
\text { appear the chief } \\
\text { audience for mate } \\
\text { displays, but they are } \\
\text { not the sole audience.) }\end{array}$ & $\begin{array}{l}\text { Winegard, } \\
\text { Winegard, \& Geary } \\
\text { (2013); Winegard, } \\
\text { Winegard, Geary, } \\
\text { \& Baumeister, (in } \\
\text { preparation). }\end{array}$ \\
\hline Men & $\begin{array}{l}\text { Male } \\
\text { Initiation } \\
\text { Rituals }\end{array}$ & $\begin{array}{l}\text { Group } \\
\text { Commitment, } \\
\text { Pain Tolerance }\end{array}$ & $\begin{array}{l}\text { Other Men. (These } \\
\text { appear mostly aimed at } \\
\text { older or high status } \\
\text { men in the community.) }\end{array}$ & $\begin{array}{l}\text { Anderson (2000); } \\
\text { Gilmore (1990); } \\
\text { Sosis, Kress, \& } \\
\text { Boster (2007); Vigil } \\
\text { (1996) }\end{array}$ \\
\hline $\begin{array}{l}\text { Primarily } \\
\text { Men }\end{array}$ & $\begin{array}{l}\text { Big Trucks or } \\
\text { Other Large } \\
\text { Vehicles }\end{array}$ & $\begin{array}{l}\text { Masculine } \\
\text { Interests }\end{array}$ & $\begin{array}{l}\text { Other Men. (Men } \\
\text { appear the chief } \\
\text { audience for such } \\
\text { vehicles, but they are } \\
\text { not the sole audience.) }\end{array}$ & $\begin{array}{l}\text { Willer, Rogalin, } \\
\text { Conlon, \& } \\
\text { Wojnowicz (2013) }\end{array}$ \\
\hline
\end{tabular}




\begin{tabular}{|c|c|c|c|c|}
\hline $\begin{array}{l}\text { Primarily } \\
\text { Men }\end{array}$ & $\begin{array}{l}\text { Classical } \\
\text { Literature } \\
\text { (e.g., Virgil, } \\
\text { Homer, Plato) }\end{array}$ & $\begin{array}{l}\text { Intelligence, } \\
\text { Knowledge of } \\
\text { Male Coalitions, } \\
\text { Loyalty and } \\
\text { Dedication to } \\
\text { Coalition }\end{array}$ & $\begin{array}{l}\text { Other Men. (Again, } \\
\text { men were certainly not } \\
\text { the sole audience.) }\end{array}$ & Tatum (2008) \\
\hline $\begin{array}{l}\text { Primarily } \\
\text { Men }\end{array}$ & $\begin{array}{l}\text { Heavy Metal } \\
\text { Music }\end{array}$ & $\begin{array}{l}\text { Aggressiveness, } \\
\text { Pain Tolerance, } \\
\text { Rebelliousness, } \\
\text { Risk Taking }\end{array}$ & $\begin{array}{l}\text { Other Men. (Not the } \\
\text { sole audience.) }\end{array}$ & Research is Needed \\
\hline $\begin{array}{l}\text { Primarily } \\
\text { Men }\end{array}$ & $\begin{array}{l}\text { Traditional/C } \\
\text { anonical } \\
\text { Western } \\
\text { Philosophy } \\
\text { (e.g., from } \\
\text { Descartes to } \\
\text { Sartre.) }\end{array}$ & $\begin{array}{l}\text { Intelligence, } \\
\text { Abstract } \\
\text { Cognitive } \\
\text { Capacities, } \\
\text { Leisure, Erudition }\end{array}$ & $\begin{array}{l}\text { Other Men. (Most of } \\
\text { the major participants } \\
\text { were men; men judged } \\
\text { and rewarded other } \\
\text { men. This has since } \\
\text { changed.) }\end{array}$ & Research is Needed \\
\hline $\begin{array}{l}\text { Men and } \\
\text { Women }\end{array}$ & $\begin{array}{l}\text { Romantic } \\
\text { (love) Poetry }\end{array}$ & $\begin{array}{l}\text { Passion, } \\
\text { Dedication, } \\
\text { intelligence, } \\
\text { Erudition, Verbal } \\
\text { Facility }\end{array}$ & $\begin{array}{l}\text { Other Women. } \\
\text { (Probably the intended } \\
\text { audience was both men } \\
\text { and women.) }\end{array}$ & Research is Needed \\
\hline $\begin{array}{l}\text { Men and } \\
\text { Women }\end{array}$ & $\begin{array}{l}\text { Musical } \\
\text { Compositions } \\
\text { (e.g. } \\
\text { "Classical" } \\
\text { Music)/Music } \\
\text { al } \\
\text { Performance }\end{array}$ & $\begin{array}{l}\text { Intelligence, } \\
\text { Leisure, Passion }\end{array}$ & $\begin{array}{l}\text { Other Men and } \\
\text { Women. (Music } \\
\text { appears one of the most } \\
\text { sex-neutral of the arts.) }\end{array}$ & $\begin{array}{l}\text { Gueguen, Meineri, } \\
\text { \& Fischer-Lokou } \\
(2014)\end{array}$ \\
\hline $\begin{array}{l}\text { Men and } \\
\text { Women }\end{array}$ & $\begin{array}{l}\text { Romantic } \\
\text { Novels/Films }\end{array}$ & $\begin{array}{l}\text { Passion, } \\
\text { Commitment, } \\
\text { Intelligence, } \\
\text { Leisure }\end{array}$ & $\begin{array}{l}\text { Other Women. (Not the } \\
\text { sole audience. Note that } \\
\text { this category does not } \\
\text { refer to "cheap" } \\
\text { romance paperbacks, } \\
\text { which are probably } \\
\text { written solely to make } \\
\text { money.) }\end{array}$ & Research is Needed \\
\hline $\begin{array}{l}\text { Men and } \\
\text { Women }\end{array}$ & $\begin{array}{l}\text { Luxury } \\
\text { clothing and } \\
\text { apparel }\end{array}$ & $\begin{array}{l}\text { Wealth, Leisure, } \\
\text { Male investment }\end{array}$ & $\begin{array}{l}\text { Other Men and } \\
\text { Women. (Scholars } \\
\text { debate whom women } \\
\text { target with prestige }\end{array}$ & $\begin{array}{l}\text { Howlet, Pine, } \\
\text { Orakcioglu, \& } \\
\text { Fletcher (2013); } \\
\text { Hudders, De }\end{array}$ \\
\hline
\end{tabular}




\begin{tabular}{|c|c|c|c|c|}
\hline & & & $\begin{array}{l}\text { clothing--some argue it } \\
\text { signals male investment } \\
\text { to rivals.) }\end{array}$ & $\begin{array}{l}\text { Backer, Fisher, \& } \\
\text { Vyncke (2014); } \\
\text { Nelissen \& Meijers } \\
\text { (2011); Townsend } \\
\text { \& Levy (1990); } \\
\text { Wang \& } \\
\text { Griskevicius (2014) }\end{array}$ \\
\hline $\begin{array}{l}\text { Men and } \\
\text { Women }\end{array}$ & $\begin{array}{l}\text { Sports' } \\
\text { Cars/Luxury } \\
\text { House/Apart } \\
\text { ment }\end{array}$ & Wealth, Leisure & $\begin{array}{l}\text { Other Men and } \\
\text { Women. }\end{array}$ & $\begin{array}{l}\text { Dunn \& Searle } \\
\text { (2010); Dunn \& } \\
\text { Hill (2014) }\end{array}$ \\
\hline Men & $\begin{array}{l}\text { Sports } \\
\text { knowledge }\end{array}$ & $\begin{array}{l}\text { Understanding } \\
\text { coalitional } \\
\text { mechanisms, } \\
\text { intelligence, } \\
\text { analytical ability }\end{array}$ & $\begin{array}{l}\text { Other men (women do } \\
\text { not seem impressed by } \\
\text { this) }\end{array}$ & $\begin{array}{l}\text { Davis \& Duncan } \\
\text { (2006); Farquhar \& } \\
\text { Meeds (2007) }\end{array}$ \\
\hline $\begin{array}{l}\text { Men } \\
\text { (almost } \\
\text { exclusively) }\end{array}$ & Dueling & $\begin{array}{l}\text { Toughness, } \\
\text { boldness, not to } \\
\text { be messed with, } \\
\text { etc. }\end{array}$ & $\begin{array}{l}\text { Mostly other men (but } \\
\text { some women) }\end{array}$ & $\begin{array}{l}\text { Kirchner (2004); } \\
\text { Wells (2001) }\end{array}$ \\
\hline $\begin{array}{l}\text { Primarily } \\
\text { Women }\end{array}$ & Cosmetics & $\begin{array}{l}\text { Youthfulness, } \\
\text { Symmetry, } \\
\text { Fertility }\end{array}$ & $\begin{array}{l}\text { Other Men. (Also } \\
\text { deterrent to women, but } \\
\text { primarily to attract } \\
\text { men. Note that men } \\
\text { also wore makeup, and } \\
\text { still do in some } \\
\text { cultures, but it appears } \\
\text { that women have been } \\
\text { the chief consumers of } \\
\text { cosmetics throughout } \\
\text { history.) }\end{array}$ & $\begin{array}{l}\text { Cash, Dawson, } \\
\text { Davis, Bowen, \& } \\
\text { Galumbeck (1989); } \\
\text { Etcoff, Stock, } \\
\text { Haley, Vickery, \& } \\
\text { House } \\
\text { (2011); Kyle, } \\
\text { Mahler (1996) }\end{array}$ \\
\hline
\end{tabular}

Note. We focused mostly on men's signals or on signals that were directly relevant to the hypotheses in this paper. This is not an exhaustive list. 